\title{
ECONOMIC IMPLICATIONS OF STATE SOVEREIGN IMMUNITY FROM INFRINGEMENT OF FEDERAL INTELLECTUAL PROPERTY RIGHTS
}

\author{
Peter S. Menell*
}

The federal intellectual property system serves as a principal means of promoting "progress in Science and useful Arts" through the provision of limited monopolies to authors and inventors. By this logic, enhancing the scope or enforceability of intellectual property rights increases the expected reward to those engaged in intellectual work, thereby spurring intellectual creativity and the exploitation of works. Inversely, impediments to the enforcement of the intellectual property rights or limitations on remedies reduce this reward stream and opportunity for exploitation, thereby dampening the incentives of those who engage in creative enterprise.

During the 1980s, intellectual property owners became concerned that a significant class of consumers of intellectual propertythe fifty states and their myriad agencies and institutions, including public universities - might escape or at least frustrate enforcement of federal intellectual property rights by invoking state sovereign immunity under the Eleventh Amendment of the U.S. Constitution. ${ }^{2}$ In

* Professor of Law, University of California at Berkeley, and Director, Berkeley Center for Law and Technology. I am grateful to Fred Abbot, Thomas Cotter, John Dwyer, Lauren Edelman, Willy Fletcher, Paul Heald, Justin Hughes, Dan Meltzer, Rob Merges, Jennifer Polse, Marty Simpson, Simon Steel, Claire Sylvia, Eugene Volokh, and John Yoo for helpful discussions and to Pratik Shah for research assistance.

1. U.S. CONST. art. I, $\S 8$, cl. 8.

2. "The Judicial power of the United States shall not be construed to extend to any suit in law or equity, commenced or prosecuted against one of the United States by Citizens of another State, or by Citizens or Subjects of any Foreign State." U.S. CONST. amend XI. The Supreme Court has interpreted this Amendment as prohibiting all suits by individuals against nonconsenting states in federal court, not only Article III diversity actions. See Hans v. Lou- 
1985, the Supreme Court held that Congress must "mak[e] its intention unmistakably clear in the language of the statute" to abrogate Eleventh Amendment immunity. ${ }^{3}$ Three years later, the Federal Circuit affirmed a decision dismissing a patent infringement action brought against the State of California on the grounds that California had not consented to jurisdiction and the Patent Act did not contain an unmistakably clear statement that Congress intended to abrogate state sovereign immunity. ${ }^{4}$ In response, Congress enacted a series of laws expressly abrogating state sovereign immunity for copyright, ${ }^{5}$ trademark, ${ }^{6}$ and patent infringement. ${ }^{7}$ In 1996, the Supreme Court in Seminole Tribe v. Florida ${ }^{8}$ raised the bar another notch in holding that Congress may not abrogate state sovereign immunity when legislating pursuant to its Article I powers. The Court noted, ${ }^{9}$ however, that Congress retains authority to abrogate state sovereign immunity pursuant to its Fourteenth Amendment remedial powers to "enforce,

isiana, 134 U.S. 1, 13, 15 (1890). See generally Patent Remedy Clarification Act: Hearing on H.R. 3886 before the Subcomm. on Courts, Intellectual Property, and the Admin. of Justice of the House Comm. on the Judiciary, 101st Cong., 2d Sess. (1990); Hearings before the Subcomm. on Patents, Copyrights and Trademarks of the Comm. on the Judiciary, United States Senate, 101st Cong., 1st Sess. (1989); Hearings Before the Subcomm. on Courts, Intellectual Property, and the Admin. of Justice of the Comm. on the Judiciary, 101st Cong., 1st Sess. (1989); A Report of the Register of Copyrights, Copyright Liability of States and the Eleventh Amendment (June 1988).

3. Atascadero State Hosp. v. Scanlon, 473 U.S. 234, 242 (1985).

4. See Chew v. California, 893 F.2d 331 (Fed. Cir. 1990) (upholding the dismissal of a patent infringement claim against a state on the ground that the Patent Act did not contain a clear statement that Congress intended to subject states to infringement liability); see also Lane v. First Nat'l Bank, 871 F.2d 166 (1st Cir. 1989) (dismissing copyright action against state entity on sovereign immunity grounds); BV Eng'g v. UCLA, 858 F.2d 1394 (9th Cir. 1988) (same); Richard Anderson Photography v. Brown, 852 F.2d 114 (4th Cir. 1988) (same).

5. Copyright Remedy Clarification Act, Pub. L. No. 101-553, 104 Stat. 2749 (1990) (codified as amended at 17 U.S.C. §§ 501(a), 511 (1994)).

6. Trademark Remedy Clarification Act, Pub. L. No. 102-542, 106 Stat. 3567 (1992) (codified at 15 U.S.C. §§ 1114(1), 1122, 1125(a), 1127 (1994 \& Supp. IV 1998)).

7. Patent and Plant Variety Protection Remedy Clarification Act, Pub. L. No. 102-560, § 2(a)(2), 106 Stat. 4230 (1992) (codified at 35 U.S.C. § 296 (1994)).

8. 517 U.S. 44 (1996).

9. See id. at 71 n.15. 
by appropriate legislation,"10 that "[n]o State shall . . . deprive any person of life, liberty, or property, without due process of law."

At the close of its 1998 Term, the Supreme Court, in Florida Prepaid Postsecondary Education Expense Board v. College Savings Bank, ${ }^{12}$ struck down the Patent and Plant Variety Remedy Clarification Act on the grounds that Congress cannot abrogate state sovereign immunity on the basis of Article I powers and that Congress had not established an adequate basis for abrogation of state sovereign immunity pursuant to the Fourteenth Amendment. In the Supreme Court's view, the legislative record on which Congress based the Patent Remedy Clarification Act established neither a "pattern of patent infringement by the States, let alone a pattern of constitutional violations," nor the lack of adequate state remedies sufficient to justify remedial measures for violations of due process rights under the Fourteenth Amendment. ${ }^{13}$ In a companion case, College Savings Bank v. Florida Prepaid Postsecondary Education Expense Board, ${ }^{14}$ the Supreme Court struck down aspects of the Trademark Remedy Clarification Act relating to false advertising claims on the ground that such violations do not intrude upon a constitutionally recognized "property right" and therefore Congress lacked power under the Fourteenth Amendment to abrogate state sovereign immunity with regard to such claims. As a result, the Court never reached the decisive question in Florida Prepaid of whether the abrogation of state sovereign immunity was necessary to prevent violation of the Fourteenth Amendment. ${ }^{15}$ The Fifth Circuit has now completed the trilogy, striking down the Copyright Remedy Clarification Act as

10. U.S. CONST. amend. XIV, § 5.

11. Id. $\S 1$.

12. 119 S. Ct. 2199 (1999).

13. Id. at $2207-10$.

14. 119 S. Ct. 2219 (1999).

15. In College Savings Bank, the Supreme Court also rejected the argument that the State of Florida had voluntarily waived its sovereign immunity by engaging in "otherwise lawful activity" such as interstate commerce, overruling its decision in Parden v. Terminal Railway of Alabama Docks Department, 377 U.S. 184 (1964). College Savings Bank, 119 S. Ct. at 2228-31. The Court confirmed, however, that Congress may compel a waiver of sovereign immunity where a state receives a "gift or gratuity" or "federal beneficence" that Congress may rightfully withhold. $I d$. at 2231 . 
beyond congressional power as delimited by the Supreme Court's Florida Prepaid decisions. ${ }^{16}$

In relying upon its prior ruling in Seminole Tribe that Congress may not abrogate state sovereign immunity under its Article I powers, and by narrowly interpreting Congress's remedial powers under the Fourteenth Amendment, the Supreme Court largely sidestepped the broader implications of its decision for federal intellectual property policy. This Article examines the effects of the constitutional constraints on federal abrogation of state sovereign immunity upon the incentives of inventors and creators of expressive works as well as the intellectual property system in general. ${ }^{17}$ The Article looks in turn at the likely effects on state infringement of intellectual property rights in the United States, the viability of alternative means of protecting federal intellectual property rights, and potential implications of the decisions for international intellectual property diplomacy. It concludes that although state sovereign immunity for violations of federal intellectual property rights is unlikely to significantly undermine the rights of intellectual property owners because of a broad array of legal, market, social, and political restraints upon states and state actors, state sovereign immunity could undermine international treaty obligations and foreign diplomacy. These latter concerns

16. See Chavez v. Arte Publico Press, 204 F.3d 601, 608 (5th Cir. 2000) (affirming district court decision to dismiss for lack of subject matter jurisdiction based on Florida Prepaid); see also Rodriguez v. Texas Comm'n on the Arts, 199 F.3d 279 (5th Cir. 2000) (same). But cf. Peter Bray, After College Savings v. Florida Prepaid, Are States Subject to Suit for Copyright Infringement? The Copyright Remedy Clarification Act and Chavez v. Arte Publico Press, 36 HoUs. L. REV. 1531 (1999) (arguing that the legislative basis for abrogating state sovereign immunity for copyright infringement may be more justifiable under the Supreme Court's Fourteenth Amendment standard on the ground that the legislative record on which the Copyright Remedy Clarification Act was based contained significant substantiation of pervasive and intentional copyright infringement by state entities).

17. The Supreme Court's rulings do not wholly divorce sovereign immunity from concerns about the integrity of the federal intellectual property system. The Court left open the possibility that Congress could, upon a greater showing of pervasive intellectual property infringement by states and the lack of adequate state remedies, abrogate state sovereign immunity to remedy violations of the Fourteenth Amendment. See Florida Prepaid, 119 S. Ct. at 2209-10. The effect of the decisions is to impose upon Congress a relatively high burden of proof. 
potentially provide an alternative basis for congressional abrogation of state sovereign immunity for infringement of federal intellectual property rights.

I. INSTITUTIONAL CONSTRAINTS UPON STATE INFRINGEMENT OF FEDERAL INTELLECTUAL PROPERTY RIGHTS

At first blush, the Supreme Court's Florida Prepaid decisions appear to afford states and state entities some enticing options for reducing the costs of providing services to their constituents. State offices could free up resources by purchasing just one copy of computer programs and making copies for all of their employees. Public schools could ease budgetary pressures while raising teacher salaries and expanding programs by setting up government-operated printing operations to reproduce textbooks for all students in the state. State universities could reduce their costs of operating laboratories and other research facilities by using patented products and processes in their laboratories without paying royalties. State hospitals could significantly reduce the costs of providing care by manufacturing patented drugs.

While these opportunities have obvious appeal, especially to state governments and institutions seeking to keep taxes and tuition low and services high, it is unlikely that states will change their policies regarding compliance with federal intellectual property laws following the Florida Prepaid decisions. Notwithstanding the $\mathrm{Su}-$ preme Court's expansive view of state sovereign immunity and the constitutional limitations upon Congress's ability to abrogate such immunity, legal, market, social, and political constraints will likely dissuade states from either adopting policies to infringe federal intellectual property rights or allowing state entities to engage in widespread or systematic infringement of federal intellectual property rights. $^{18}$

18. See generally John P. DWYeR \& PETER S. MENell, PROPERTY LAW AND POlicy: A COMPARATIVE INSTITUTIONAL PERSPECTIVE (1998) (laying out a general multi-institutional framework for understanding governance of resources). 
A. Legal Constraints on Infringement of Intellectual Property Rights by States

The Supreme Court's Florida Prepaid decisions do not foreclose intellectual property owners from seeking legal recourse for infringement of their intellectual property rights by states and state officials, although full enforcement of federal intellectual property rights will undoubtedly be more costly, time-consuming, and complicated. Intellectual property owners may still obtain injunctive relief against state actors in federal court to prevent violations of their rights. Although they cannot directly obtain damages for infringement from states, they may nonetheless be able to obtain comparable relief through actions against state officials in their individual capacity and through inverse condemnation actions under the Fourteenth Amendment. Furthermore, they can seek recourse within the state court system under various theories. The availability and nature of relief, however, will depend upon additional circumstances beyond those involved in traditional intellectual property enforcement actions.

\section{Federal causes of action}

Intellectual property owners may still bring federal actions against municipalities and state and municipal employees in their individual capacity. Under the doctrine of Ex parte Young, ${ }^{19}$ owners may still be able to obtain injunctive relief against state officials who infringe federal intellectual property rights. The Eleventh Amendment bars intellectual property owners from obtaining direct retrospective monetary relief from states in federal court, but comparable relief may be available through actions pursuant to the Fourteenth Amendment for inverse condemnation of federal intellectual property rights. In addition, intellectual property owners might be able to obtain attorney fees in federal actions by asserting $\S 1983$ claims.

\section{a. federal intellectual property claims}

In understanding the effect of the Florida Prepaid decisions, it is important to distinguish among the range of public bodies and employees within the states for purposes of applying Eleventh

19. 209 U.S. 123 (1908). 
Amendment sovereign immunity. The Supreme Court has long held that municipalities, while public, are not state entities within the meaning of the Eleventh Amendment. ${ }^{20}$ Therefore, intellectual property owners may sue municipalities and municipal workers in state court without regard to the Florida Prepaid decisions. Thus, many public entities within the states-including cities, school boards, public utilities, regional transportation authorities, county hospitals, and some community colleges-remain subject to suit in federal court for violations of the intellectual property laws.

Following the Florida Prepaid decisions, there may be more disputes as to whether a hybrid entity "is to be treated as an arm of the State partaking of the State's Eleventh Amendment immunity, or instead to be treated as a municipal corporation or other political subdivision to which the Eleventh Amendment does not extend."21 In making this determination, courts examine a range of factors including how the entity is treated under state law, the entity's sources of funding, the nature of the governmental function performed, and the extent to which the entity is subject to state control. ${ }^{22}$

If a state entity infringes federal intellectual property rights, the intellectual property owner may nevertheless bring an enforcement action in federal court to enjoin such infringement by the state entity or official. The key in doing so is to lodge the action against the responsible state official in his or her official capacity. In Ex parte Young, the Supreme Court held that "a suit against individuals for the purpose of preventing them as officers of a State from enforcing an unconstitutional enactment to the injury of the rights of the plaintiff, is not a suit against the State within the meaning of [the Eleventh] Amendment." 23 The doctrine of Ex parte Young applies to

20. See Missouri v. Jenkins, 495 U.S. 33, 56 n.20 (1990) (holding that school boards are not protected by the Eleventh Amendment); Monell v. Department of Soc. Servs., 436 U.S. 658, 690 n.54 (1978); Lincoln County v. Luning, 133 U.S. 529, 530 (1890). The District of Columbia is treated as a municipality. See Dorman v. District of Columbia, 888 F.2d 159, 162 (D.C. Cir. 1989).

21. Mount Healthy Sch. Dist. Bd. of Educ. v. Doyle, 429 U.S. 274, 280 (1977).

22. See generally MARTIN A. SCHWARTZ \& JOHN E. KIRKLIN, SECTION 1983 LITIGATION: CLAIMS AND DEFENSES 180-87 (3d ed. 1997) (summarizing cases applying this analysis).

23. 209 U.S. at 154 (quoting Smyth v. Ames, 169 U.S. 466, 518-19 (1898)). 
some state violations of federal law, whether or not the state violates constitutional rights. ${ }^{24}$

The Ex parte Young doctrine, however, is subject to a number of limitations. A plaintiff must normally exhaust state "legislative" and "administrative" remedies before seeking relief in federal court, ${ }^{25}$ although the plaintiff need not exhaust state "judicial" remedies. ${ }^{26}$ Furthermore, the Ex parte Young doctrine does not extend to retrospective financial liability. ${ }^{27}$ Therefore, intellectual property owners cannot obtain monetary relief directly from the state. ${ }^{28}$ In addition, states may use the power of eminent domain to effectuate a taking of intellectual property rights. ${ }^{29}$ In such a case, the intellectual property owner will not be able to obtain injunctive relief, but would be entitled to "just compensation." Such compensation could, however, be less than what the intellectual property owner would be entitled to in a traditional infringement action. ${ }^{30}$ In addition, the Supreme Court ruled that injunctive relief under the Ex parte Young doctrine is not available to enforce federal statutes that contain comprehensive enforcement mechanisms inconsistent with an injunctive remedy in federal court. ${ }^{31}$ This narrowing of the Ex parte Young doctrine

See generally ERWIN CHEMERINSKY, FEDERAL JURISDICTION $\S 7.5 .1$ (3d ed. 1999) (discussing Ex parte Young doctrine).

24. See Green v. Mansour, 474 U.S. 64, 68 (1985); CHEMERINSKY, supra note $23, \S 7.5 .1$, at $413, \S 7.5 .2$, at 429 .

25. See Gilchrist v. Interborough Rapid Transit Co., 279 U.S. 159, 208-09 (1929).

26. See City Bank Farmers' Trust Co. v. Schnader, 291 U.S. 24 (1934). See generally CHARLES A. WRIGHT, LAW OF FEDERAL COURTS 312-13 (5th ed. 1994) (discussing exhaustion of state remedies).

27. See Edelman v. Jordan, 415 U.S. 651, 663 (1974).

28. Damages can be sought from the state officer in his or her individual capacity for past harms, regardless of whether the state has an indemnification policy. See Kentucky v. Graham, 473 U.S. 159, 166 (1985); Foulks v. Ohio Dep't of Rehabilitation \& Correction, 713 F.2d 1229, 1233 (6th Cir. 1983).

29. Cf. Ruckelshaus v. Monsanto Co., 467 U.S. 986 (1984). The Court in Ruckelshaus commented that injunctive relief "is not available to enjoin an alleged taking of private property for public use, duly authorized by law, when a suit for compensation can be brought against the sovereign subsequent to the taking." Id. at 1016. The intellectual property owner would have to pursue an inverse condemnation claim. In any case, however, the intellectual property owner would have some recourse.

30. See infra Part I.A.2.a.

31. See Seminole Tribe v. Florida, 517 U.S. 44, 76 (1996). See generally Daniel J. Meltzer, The Seminole Decision and Sovereign Immunity, 1996 SUP. 
should not prevent intellectual property owners from pursuing injunctive relief against states to prevent infringement of their rights. It can be argued that Congress clearly intended that such relief should be available against states. Furthermore, Congress can clarify this intent through new legislation.

The Florida Prepaid decisions will have their most significant effect with regard to efforts by intellectual property owners to obtain monetary relief for past infringement by state entities in actions brought pursuant to the federal intellectual property statutes. Nonetheless, intellectual property owners may be able to proceed directly against state officials in their individual capacity. ${ }^{32}$ Federal copyright, patent, and trademark law expressly authorize lawsuits against "any person" who violates these respective regimes. The Florida Prepaid decisions do not appear to prevent intellectual property owners from proceeding directly against state officials and employees in their individual capacities for violating federal intellectual property rights.

For example, if the office manager of a state agency copies and distributes copyrighted word-processing software among all of the employees in his division, then the intellectual property owner could sue the office manager directly for infringement remedies, including monetary damages. The principal difference between this lawsuit and a lawsuit against an office manager for a private company who engages in the same conduct is that the state employee could try to invoke qualified immunity. Public employees "generally are shielded from liability for civil damages insofar as their conduct does not violate clearly established statutory or constitutional rights of which a reasonable person would have known." copying of copyrighted material might fall within the scope of this immunity, such as copying for research or educational purposes, ${ }^{34}$

CT. ReV., 1, 36-48.

32. See, e.g., Richard Anderson Photography v. Brown, 852 F.2d 114, 122 (4th Cir. 1988) (holding that a state actor could be sued in her individual capacity for past damages under the Copyright Act).

33. Harlow v. Fitzgerald, 457 U.S. 800, 818 (1982). See Lane v. First National Bank, 687 F. Supp. 11, 15-17 (D. Mass. 1988) (considering claim of qualified immunity in an infringement action against state employee's in their individual capacities).

34. These activities might be justified under the fair use exception to the Copyright Act. See Copyright Act, 17 U.S.C. § 107 (1994 \& Supp. IV 1998) 
outright reproduction of entire software programs would likely be outside of qualified immunity. Furthermore, the intellectual property owner can diminish the scope of this immunity by sending a cease and desist demand that puts the alleged infringer on notice of the rights infringed.

More significantly, in the only appellate case to have considered qualified immunity of state employees for infringement of federal intellectual property rights, the Fourth Circuit found the defense inapplicable. In Richard Anderson Photography v. Brown, ${ }^{35}$ a photographer sued a state university, its governing board, and its public relations director for infringing his copyrighted photographs. While dismissing the actions against the state university and its employees in their official capacity under the Eleventh Amendment, the Fourth Circuit allowed the suit against the public relations director in her individual capacity to go forward. The court rejected a qualified immunity defense on the ground that the Supremacy Clause precludes states from diminishing the scope of protection for works protected by federal copyright law and therefore overrides any state authorized immunity afforded to state employees. ${ }^{36}$ This reasoning has been adopted in the only subsequently reported case addressing qualified immunity for state employee infringement of federal intellectual property rights. $^{37}$

The fact that state governments require or authorize indemnification of state employees for some forms of liability attributable to accidents and other exposures arising from conduct within the course and scope of their employment ${ }^{38}$ does not bring such awards within the scope of the Eleventh Amendment. Even though such indemnification is paid out of state funds, the Supreme Court does not view such payments as violating the Eleventh Amendment. ${ }^{39}$

(multifactor test).

35. 852 F.2d 114 (4th Cir. 1988), cert. denied, 489 U.S. 1033 (1989).

36. See id. at 122-23.

37. See Kersavage v. University of Tenn., 731 F. Supp. 1327, 1330-32

(E.D. Tenn. 1989).

38. See generally 1 Jon L. Craig, Civil Actions Against STATE AND LOCAL GOVERNMENT § 3.20, at 248-53 (2d ed. 1992) (collecting indemnification provisions of 36 states).

39. See supra note 28 and accompanying text. 
It is also possible that private actors will be able to obtain declaratory relief in federal court against states threatening to enforce state-owned intellectual property rights. Federal law allows a person to seek declaratory relief in federal court regarding the validity or enforceability of a U.S. patent if the patent owner had caused a reasonable apprehension that an infringement claim will be lodged against that person and that person has a sufficient interest at stake with regard to the patent. ${ }^{40}$ Thus, a company that receives a cease and desist letter from a patent owner threatening an infringement action against the company may seek a declaratory judgment that the patent in question is either invalid or not infringed by the company's activities. $^{41}$ The ability to bring such declaratory judgment actions can be of significant importance in exercising rights in the marketplace and pursuing a business strategy. For example, the cloud of infringement liability can greatly undermine a company's ability to raise money or introduce new products in the marketplace.

The Supreme Court's Florida Prepaid decisions do not directly address whether states can be sued in federal court for declaratory relief. College Savings Bank confirms, however, that Congress may compel a waiver of sovereign immunity where a state receives a "gift or gratuity" or "federal beneficence" that Congress may rightfully withhold. $^{42}$ One district court has interpreted this language as supporting declaratory judgment actions for patent invalidity against states in federal court. ${ }^{43}$

It is not clear whether the Supreme Court views patents as falling within the categories of gifts, gratuities, or beneficence for which Congress may compel waiver. On the day following the issuance of the Florida Prepaid decisions, the Supreme Court vacated and remanded for reconsideration in light of College Savings Bank a decision by the Federal Circuit holding that the University of California had consented to declaratory judgment actions by obtaining

40. See Declaratory Judgment Act, 28 U.S.C. § 2201 (1994).

41. See, e.g., Shell Oil Co. v. Amoco Corp., 970 F.2d 885, 888 (Fed. Cir. 1992).

42. College Sav. Bank v. Florida Prepaid Postsecondary Educ. Expense Bd., 119 S. Ct. 2219, 2231 (1999).

43. See New Star Lasers, Inc. v. Regents of the Univ. of Cal., 63 F. Supp. $2 d 1240,1243-45$ (E.D. Cal. 1999) (rejecting Regents' motion to dismiss declaratory judgment action on grounds of sovereign immunity). 
patents-that by their nature can be adjudicated only in federal court-and threatening enforcement actions in federal court. ${ }^{44}$ The basis for federal jurisdiction to hear declaratory judgment actions against states is strong. The Eleventh Amendment should not provide states preferential treatment in exercising rights under federal intellectual property law.

\section{b. inverse condemnation claims}

Even though the Eleventh Amendment shields states from direct liability for infringement of federal intellectual property rights, intellectual property owners may nonetheless obtain "just compensation" for the taking of their property under the Fifth and Fourteenth Amendments. ${ }^{45}$ Because of the availability of direct infringement actions against states prior to the Florida Prepaid decisions (and the paucity of reported incidents of infringements by states), no court has yet applied takings analysis directly to state infringement of intellectual property rights. ${ }^{46}$ The law is clear, however, that the Takings Clause applies to intangible as well as tangible forms of property.

44. See Regents of Univ. of Cal. v. Genentech, Inc., 119 S. Ct. 2388 (1999) (remanding Genentech, Inc. v. Regents of the Univ. of Cal., 143 F.3d 1446, 1454 (Fed. Cir. 1998)).

45. See Dolan v. City of Tigard, 512 U.S. 374, 383-84 (1994); Chicago, Burlington \& Quincy R.R. v. City of Chicago, 166 U.S. 226, 241 (1897) (applying the Takings Clause of the Fifth Amendment to the states through the Fourteenth Amendment).

46. This issue has not arisen with regard to federal government infringement of patents and copyrights because Congress has, since 1910, authorized intellectual property owners to sue the federal government to recover for use of intellectual property. See 28 U.S.C. $\S 1498$. This section has been interpreted as a form of eminent domain, see Irving Air Chute Co. v. United States, $93 \mathrm{~F}$. Supp. 633, 635 (Ct. Cl. 1950), under which the federal government may condemn a license for the shorter of the period of infringing use or the life of the intellectual property right. See Motorola, Inc. v. United States, 729 F.2d 765, 768 (Fed. Cir. 1984); Pitcairn v. United States, 547 F.2d 1106, 1114 (Ct. Cl. 1977). Courts interpret this provision as equating infringement with "an eminent domain taking." Tektronix, Inc. v. United States, 552 F.2d 343, 346 (Ct. Cl. 1977). The federal government formally waived its immunity from Lanham Act infringement in 1999, see Pub. L. No. 106-43, § 4, 113 Stat. 218 (Aug. 5, 1999), although courts had previously held that the Federal Torts Claims Act waived such immunity for trademark infringement. See generally J. THOMAS MCCARTHY, MCCARTHY ON TRADEMARKS AND UNFAIR COMPETITION § 25:63, at 25-124 (1999). 
The Supreme Court held, more than 150 years ago, that Vermont could validly take a franchise to a toll bridge crossing and convert it into a free public road upon payment of compensation to the owner of the franchise. ${ }^{47}$ More recently, the Supreme Court has held that interest on a bank account constitutes property under the Takings Clause. ${ }^{48}$ The Supreme Court has recognized that patents, ${ }^{49}$ trade secrets, ${ }^{50}$ and trademarks ${ }^{51}$ constitute property within the meaning of the Takings Clause, emphasizing the right to exclude as the "hallmark of a protected property interest." $"$ "This same reasoning would bring copyrights within the class of property rights protected by the

47. See West River Bridge Co. v. Dix, 47 U.S. 507 (6 How.) (1848).

48. See Phillips v. Washington Legal Found., 524 U.S. 156 (1998).

49. See Hartford-Empire Co. v. United States, 323 U.S. 386, 415 (1945) ("That a patent is property, protected against appropriation both by individuals and by government, has long been settled." (footnote omitted)); James v. Campbell, 104 U.S. 356, 357-58 (1881) (analogizing a utility patent to a land patent for takings analysis).

50. See Ruckelshaus v. Monsanto Co., 467 U.S. 986 (1984).

51. See Trade-Mark Cases, 100 U.S. 82, 92 (1879) ("The right to adopt and use a symbol ... to the exclusion of use by all other persons . . . is a property right for the violation of which damages may be recovered in an action at law.") In College Savings Bank v. Florida Prepaid Postsecondary Education Expense Board, Justice Scalia commented that:

The Lanham Act may well contain provisions that protect constitutionally cognizable property interests-notably, its provisions dealing with infringement of trademarks, which are the "property" of the owner because he can exclude others from using them. See, e.g., K mart Corp. v. Cartier, Inc., 485 U.S. 176, 185-86, 108 S. Ct. 950, 99 L. Ed. 2d 151 (1988) ("Trademark law, like contract law, confers private rights, which are themselves rights of exclusion. It grants the trademark owner a bundle of such rights").

$119 \mathrm{~S}$. Ct. at 2224. He went on to note that the Lanham Act's rights against false advertising are not rights to exclude and therefore do not constitute property rights protected by the Fourteenth Amendment. See id. at 2224-25.

52. Id. at 2224. See generally Christina Bohannan \& Thomas F. Cotter, When the State Steals Ideas: Is the Abrogation of State Sovereign Immunity from Federal Infringement Claims Constitutional in Light of Seminole Tribe?, 67 FORDHAM L. REV. 1435, 1480-81 (1999); Thomas F. Cotter, Do Federal Uses of Intellectual Property Implicate the Fifth Amendment?, 50 FLA. L. REV. 529 (1998); Paul J. Heald \& Michael L. Wells, Remedies for the Misappropriation of Intellectual Property by State and Municipal Governments Before and After Seminal Tribe: The Eleventh Amendment and Other Immunity Doctrines, 55 WASH. \& LEE L. REV. 849, 857-64 (1998). 
Takings Clause. ${ }^{53}$ Therefore, there is a reasonable basis for asserting that state infringement of intellectual property rights would constitute a compensable taking.

Intellectual property owners will, however, encounter substantial hurdles in pursuing takings claims against states in federal court. In Williamson County Regional Planning Commission v. Hamilton Bank, $^{54}$ the Supreme Court held that a takings claim brought in federal court against a local planning authority would not be ripe for federal adjudication until the property owner had obtained a final decision regarding the application of the zoning ordinance to his property and had sought compensation through state procedures. ${ }^{55}$ Property owners may, however, pursue a facial challenge to the constitutionality of state action without exhausting state remedies. ${ }^{56}$ Since the infringement of intellectual property rights by a state will generally not be accomplished through a state statute and in any case will generally turn on factual questions, this exception to the Williamson ripeness rule will rarely if ever apply in this context.

The resolution of the takings claim at the state level may have the practical effect of barring the federal proceeding under principles of res judicata (claim preclusion), collateral estoppel (issue preclusion), and affording full faith and credit to decisions of competent courts. ${ }^{57}$ Intellectual property owners will get their day in court to

53. See Bohannan \& Cotter, supra note 52 , at $1480-81$ (noting that "the traditional view of property likely encompasses rights against patent, copyright, and trademark infringement").

54. 473 U.S. 172 (1985).

55. See id. at 186. Some courts have held that a federal takings suit is not ripe until the claimant has exhausted state appellate review as well. See, e.g., Belvedere Military Corp. v. County of Palm Beach, 845 F. Supp. 877, 878 (S.D. Fla. 1994).

The Supreme Court's 1997 decision in Suitum v. Tahoe Regional Planning Agency, 520 U.S. 725, 733-34, however, suggests that the Williamson ripeness requirement is only prudential. If this dictum does bring Williamson outside of Article III, then Congress could presumably eliminate such a requirement. See Bohannan \& Cotter, supra note 52, at 1470-71 n.217.

56. See Yee v. City of Escondido, 503 U.S. 519, 534 (1992).

57. See Wilkinson v. Pitkin County Bd. of County Comm'rs, 142 F.3d 1319, 1319, 1325 n.4 (10th Cir. 1998) (expressing "concern that Williamson's ripeness requirement may, in actuality, almost always result in preclusion of federal claims"); see also 144 CONG. REC. S8,024 (1998) (citing study by law firm of Linowes and Blocker L.L.P., Silver Spring, Md., finding that federal 
pursue takings or inverse condemnation claims against states, but it will not likely be in a federal district court. Decisions of a state's highest court reviewing a takings claims would, however, be appealable to the U.S. Supreme Court. As a result of these ripeness and preclusion doctrines, intellectual property owners will need to navigate state administrative and judicial processes in order to obtain damages (or "just compensation") for infringement of federal intellectual property rights directly from states.

\section{State causes of action}

In addition to these bases for federal jurisdiction, intellectual property owners whose rights are violated by states or state actors may potentially pursue a variety of remedies in state courts and through state administrative processes where states have authorized suits or other remedies. These avenues of recourse are generally inferior to federal relief under the intellectual property statutes and hence there was little incentive for intellectual property owners to pursue these remedies for state infringement of federal intellectual property rights prior to the Florida Prepaid decisions. The closing of the federal courthouses to traditional infringement actions directly against states will undoubtedly encourage intellectual property owners to pursue creative, and in some circumstances largely untested, approaches to enforcement of intellectual property rights against states and state actors in state courts and administrative tribunals. Unlike federal remedies, however, these modes of legal recourse vary across jurisdictions. This was one of the principal motivations and justifications for enacting the federal remedy clarification acts. ${ }^{58}$

district courts dismissed more than $80 \%$ of takings claims on ripeness grounds between 1990 and 1997); JAN G. LAITOS, LAW OF PROPERTY RIGHTS PROTECTION: LIMITATIONS ON GOVERNMENTAL POWERS $§ 10.05$ [A] (1999 \& Supp. 2000); G. Overstreet, The Ripeness Doctrine of the Takings Clause: $A$ Survey of Decisions Showing Just How Far Federal Courts Will Go to Avoid Adjudicating Land Use Cases, 10 J. LAND UsE \& ENVTL. L. 91 , 91 n.3 (1994) (reporting that only 5.6\% of land-use cases filed in federal court between 1983 and 1988 were ripe); Gregory M. Stein, Regulatory Takings and Ripeness in the Federal Courts, 48 VAND. L. REV. 1, $92-97$ (1995). Such preclusion might not apply in some circumstances. See RESTATEMENT (SECOND) OF JUDGEMENTS $\S \S 26,28$.

58. See Patent Remedy Clarification Act: Hearing on H.R. 3886 Before the Subcomm. on Courts, Intellectual Property, and the Admin. of Justice of the 


\section{a. inverse condemnation claims}

Intellectual property owners can invoke state inverse condemnation procedures in order to pursue compensation for the infringement of their intellectual property rights by the state. All states afford protection against governmental takings of private property without due process or compensation through their own laws. The constitutions of most states have analogs to the Fifth Amendment's Takings Clause, ${ }^{59}$ and many states have enacted specific statutes setting forth procedures for pursuing inverse condemnation actions. ${ }^{60}$ Since the actual appropriation of property for public use is considered an act of eminent domain, ${ }^{61}$ an intellectual property owner would be able to claim that infringement of their intellectual property rights by the state triggers an obligation to provide compensation. As noted by the Supreme Court in Florida Prepaid, ${ }^{62}$ the Florida Supreme Court has ruled that intellectual property owners may pursue an inverse condemnation action where the state infringes federal intellectual property rights. ${ }^{63}$

House Comm. on the Judiciary, 101st Cong. 34, 41 (1990) (testimony of Professor Robert P. Merges) (noting that variation among state law procedures and remedies could discourage enforcement of rights and undermine a nationally uniform system of intellectual property rights).

59. See 1 JULIUS SACKMAN, NICHOLS ON EMINENT DOMAIN $\S 1.3$ (rev. 3d ed. 1998) (noting that North Carolina is the only state lacking such a provision).

60. See, e.g., ARIZ. REV. STAT. ANN. § 11-972 (West 2000); Cal. Civ. PROC. CODE $\S \S 1250.110,1268.350$ (West 2000); Colo. REV. STAT. $\S 24-56-$ 116 (West 2000); CONN. GEN. STAT. ANN. § 48-17b (West 2000); DEL. CODE ANN. tit. 95, § 9504 (1999); HAW. REV. STAT. § 113-4 (1999); N.C. GEN. STAT. § 40A-51 (1999); OR. REV. STAT. § 20.085 (1998); VT. STAT. ANN. tit. $19, \S 512$ (1999); VA. CODE ANN. $\S 8.01-187$ (Michie 1999); WYO. STAT. ANN. $\S 1-26-516$ (Michie 2000). Some states offer a separate administrative remedy for recovering from the state.

61. See 1 SACKMAN, supra note $56, \S 1.42[1]$.

62. See 119 S. Ct. at 2209 n.9.

63. See Jacobs Wind Elec. Co. v. Department of Transp., 626 So. 2d 1333, 1336 (Fla. 1993); see also Wilcox Indus., Inc. v. State, 607 N.E.2d 514, 515 (Ohio 1992) (concluding that patent rights are property rights that may be protected in inverse condemnation action); $c f$. Jacobs Wind Elec. Co. v. Florida Dep't of Transp., 919 F.2d 726, 728 n.2 (Fed. Cir. 1990) (commenting that "[w] hat a patentee may arguably 'lose' through being limited to a 'takings' claim or similar state court proceeding is not the ability to obtain any remedy, but the benefit of provisions in the patent statute relating to remedy, for example, the provisions of 35 U.S.C. $\$ \$ 284$ and 285 (1988) relating to enhanced 
In order to recover in an inverse condemnation action, a claimant must typically show (1) ownership of a property right; (2) that the defendant substantially participated in some activity for public use or benefit; (3) that the property right was taken or damaged, thereby suffering loss or diminution in value; and (4) that the government's activity was the proximate or substantial cause of the taking or damage. $^{64}$

The ownership element parallels requirements of federal intellectual property law. The second element could present a problem in some circumstances. In California, for example, injury must result from a deliberate act for the purpose of fulfilling a public objective. Negligent acts committed during the routine operation of the public entity do not give rise to a claim. ${ }^{65}$ This could be a problem in some areas of federal intellectual property law, such as the fair use doctrine ${ }^{66}$ where the line demarcating infringement is notably vague. Nevertheless, in view of the constitutional basis of inverse condemnation, the claimant does not have to prove that the defendant had statutory authority to exercise the power of eminent domain. ${ }^{67}$ There are, however, some federal cases suggesting that a takings claimant must prove that the state actor's conduct resulting in the deprivation of private property was "duly authorized by law,"68 although the degree of such authorization has not been clearly established in the case law. ${ }^{69}$

There could also be difficulty in applying the third element: determining whether property has been taken. ${ }^{70}$ In the case of

damages and attorney fees").

64. See, e.g., Albers v. County of Los Angeles, 62 Cal. 2d 250, 398 P.2d 129, 42 Cal. Rptr. 89 (1965); 2 NORMAN E. MATTEONI, CONDEMNATION PRACTICE IN CALIFORNIA $§ 13.3$ (1998).

65. See Bauer v. County of Ventura, 45 Cal. 2d 276, 289 P.2d 1 (1955).

66. See 17 U.S.C. $\$ 104$ (1994).

67. "All that is necessary to show is that the damage resulted from an exercise of governmental power while seeking to promote "the general interest in its relation to any legitimate object of government'." Baker v. BurbankGlendale-Pasadena Airport Auth., 39 Cal. 3d 862, 867, 705 P.2d 866, 868, 218 Cal. Rptr. 293, 295 (1985).

68. Ruckelshaus v. Monsanto Co., 467 U.S. 986, 1016 (1984) (footnote omitted).

69. See Bohannan \& Cotter, supra note 52, at 1475-77.

70. Cf. Cotter, supra note 52, at 529. 
tangible property, only one person can enjoy exclusive use of real estate or a tangible asset at any given time. Intellectual property, by contrast, can be enjoyed by many simultaneously, an attribute referred to as nonrivalrous consumption. For example, many automobile manufacturers can make use of the knowledge necessary to make intermittent windshield wipers. Therefore, the government's use of the intellectual property does not technically prevent others from making use of the same ideas or information. The better view would be that infringement of intellectual property constitutes a taking because it deprives the owner of the intellectual property of a return stream. ${ }^{71}$ Without this ability to appropriate a reward for investment and creativity, there would be little incentive to pursue costly, difficult, and often valuable forms of innovation.

The measure of damages in an inverse condemnation action is generally the fair market value of the property taken. ${ }^{72}$ The date of valuation is generally the date the taking or injury occurred. A property owner who prevails may also recover prejudgment interest from the date of the taking or damage. A prevailing plaintiff is also entitled to attorney fees and reimbursement of costs. ${ }^{73}$ While some of these remedies are more generous than federal causes of action, which, for example, do not provide for attorney fees except in extraordinary circumstances, ${ }^{74}$ the compensation award will likely fall below the damages available under the federal intellectual property statutes. $^{75}$ The compensation will, however, approximate that

71. The Supreme Court's references to intellectual property rights as falling within the ambit of the Takings Clause definition of property rights supports this view. See Heald \& Wells, supra note 52, at 857-64; supra notes 47-58 and accompanying text.

72. See 2 MATTEONI, supra note $61, \S 13.6$.

73. See id. $\S 17.10-.11$.

74. See 17 U.S.C. $\S 505$ (affording district courts discretion to award costs and attorney's fees in copyright actions); 35 U.S.C. $§ 285$ (1994) (authorizing district courts resolving patent cases to award attorney's fees to the prevailing party in "exceptional cases"); Fogerty v. Fantasy, Inc., 510 U.S. 517 (1994) (rejecting automatic award of attomey's fees to prevailing party in copyright actions).

75. Damages under federal patent law "shall be adequate to compensate for the infringement, but in no event less than a reasonable royalty for the use made of the invention by the infringer, together with interest and costs as fixed by the court .... [T] [The court may increase the damages up to three times the amount found or assessed." 35 U.S.C. $§ 284$. Copyright law provides for 
available to intellectual property owners for infringement of their rights by the federal government. ${ }^{76}$

If an intellectual property owner cannot recover for infringement of their federal intellectual property rights through a state inverse condemnation action, then he or she should be able to bring an action for violation of their federal constitutional rights under the Fifth and Fourteenth Amendments because the state would not have provided an adequate remedy for the taking of the intellectual property owner's property.

\section{b. tort claims}

In addition to inverse condemnation claims, intellectual property owners may be able to protect their rights and obtain compensation by pursuing a variety of tort claims against the state, state agencies, and state actors. In appropriate circumstances, an intellectual property owner may be able to cast aspects of the injurious state conduct under tort causes of action such as conversion, unjust enrichment, misappropriation, unfair competition, deceit, and misrepresentation. $^{77}$ In order to prevail, however, the claimant would need to overcome sovereign immunity, preemption, and substantive law hurdles.

The doctrine of sovereign immunity shields states from lawsuits in their own courts without their consent. ${ }^{78}$ Furthermore, states may not be held liable in their own courts for torts committed by their officers, agents, or employees unless they have waived their immunity. ${ }^{79}$ The basis for this doctrine- that the sovereign could not be sued - originated in the context of monarchical, religious rule where "the King could do no wrong." This historical basis has gradually given way in democratic societies to a more utilitarian justification

award of the copyright owner's actual damages and any additional profits or, in cases where damages are minimal, statutory damages. See 17 U.S.C. $§ 504$.

76. See supra note 46 .

77. The elements of these torts are set forth in RESTATEMENT (SECOND) OF TORTS (1965). See also W. PAGE KEETON ET AL., PROSSER AND KEETON ON THE LAW OF TORTS 88-92 (5th ed. 1984) (setting out the elements).

78. See RESTATEMENT (SECOND) OF TORTS § 895B (1965) (collecting state positions on governmental immunity); CRAIG, supra note $35, \S 1.1$ (collecting case law authority for most states).

79. See 1 CRAIG, supra note $38, \S 1.1$. 
emphasizing social policy considerations such as protecting the state from interference with the execution of governmental functions. ${ }^{80}$ Most states have abolished sovereign immunity for tort claims against the state directly and on the basis of respondeat superior in whole or part. ${ }^{81}$ Some states have enacted open-ended waivers of liability which allow for all suits against the state unless expressly excepted. $^{82}$ Others have retained sovereign immunity subject to specific exceptions. ${ }^{83}$ Some states authorize their legislatures to consider special bills or resolutions to provide compensation on individual claims. ${ }^{84}$

Notwithstanding their sovereign immunity waivers, many states impose procedural requirements and limits on recovery applicable to suits against the sovereign (and state employees). Most states require that a notice of a tort claim be filed with the state and that administrative remedies be exhausted prior to commencing legal action. ${ }^{85}$ Many states establish special courts, boards, or commissions that have exclusive jurisdiction over claims against the state. In others, a claimant proceeds to state court after the claim has been presented to the special board or commission. ${ }^{86}$ Some states limit the total amount and types of damages that may be awarded. ${ }^{87}$

Assuming that they can lodge an action against the state and apart from limits on recovery, intellectual property owners face significant additional hurdles to recovery under state tort causes of action. Federal law preempts any other "legal or equitable rights that are equivalent to any of the exclusive rights within the general scope of copyright ${ }^{388}$ and state laws that conflict with or undermine the

80. See 72 AM. JUR. 2D State and Local Taxation § 99 (1974).

81. See 57 AM. JUR. 2D Municipal, County, School, and State Tort Liability $\S 129$ (1988) (collecting Tort Claims Acts of every state).

82. See 1 CRAIG, supra note $38, \S 3.5$, at $188-92$ (collecting statutes).

83. See id. § 3.5 at 192-94 (collecting statutes).

84. See, e.g., Fla. STAT. ANN. § 11.065 (West 1999); GA. CODE ANN. § 28-5-83 (1999). Some state constitutions prohibit state legislatures from passing special legislation to compensate for claims against the state. See, e.g., IND. CONST. art. 4, § 24; see also 1 CRAIG, supra note 38, § 3.11.

85. See 1 CraIG, supra note 38 , ch. 5 .

86. See id. $\S \S 3.7-.8$.

87. See id. $\S \S 6.7-.16$.

88. 17 U.S.C. § 301(a). 
comprehensive federal regime for protecting inventions. ${ }^{89}$ Nonetheless, the federal regime does not preclude all state causes of action that protect creativity and innovation. The Copyright Act does not preempt state laws that require, in order to establish liability, proof of an "extra element" beyond those required to prove infringement of one of the exclusive rights granted by federal copyright law. ${ }^{90}$ On this basis, the Second Circuit held that copyright law does not preempt a state misappropriation claim requiring proof that the defendant had appropriated time sensitive information in such a manner as to threaten the existence of the product or service provided by the plaintiff. ${ }^{91}$ The Ninth Circuit has found that the Copyright Act does not preempt claims requiring proof of conversion of a physical object and claims based on breach of a fiduciary duty. ${ }^{92}$

Similarly, federal patent law does not preempt a state law tort claim

even if it requires the state court to adjudicate a question of federal patent law, provided the state law cause of action includes additional elements not found in the federal patent law cause of action and is not an impermissible attempt to offer patent-like protection to subject matter addressed by federal law. ${ }^{93}$

Courts have held that federal patent law does not, in general, preempt state unfair competition ${ }^{94}$ or misappropriation doctrines. ${ }^{95}$

89. See Bonito Boats, Inc. v. Thunder Craft Boats, Inc., 489 U.S. 141 (1989). See generally ROBERT P. MERGES ET AL., INTELlECTUAL PROPERTY IN THE NEW TECHNOLOGICAL AGE (2d ed. 2000) (discussing federal preemption of state law).

90. See National Basketball Ass'n v. Motorola, Inc., 105 F.3d 841 (2d Cir. 1997); see also Nicholas Khadder, National Basketball Association v. Motorola, Inc., Annual Review of Law \& Technology, 13 BERKELEY TECH. L.J. 3 (1998) (summarizing case and history of misappropriation doctrine).

91. See National Basketball, 105 F.3d at 853; National Car Rental Sys., Inc. v. Computer Assocs., Int'l, Inc., 991 F.2d 426 (8th Cir. 1993); see also Smith v. Weinstein, 578 F. Supp. 1297, 1307 (S.D.N.Y. 1984) (finding that writer's unfair competition claim which sought to recover profits derived from use of his ideas was preempted by federal copyright law, but that breach of contract and confidential relationship claims were not), aff'd, 738 F.2d 419 (2d Cir. 1984).

92. See Oddo v. Ries, 743 F.2d 620, 636 (9th Cir. 1984).

93. Dow Chem. Co. v. Exxon Corp., 139 F.3d 1470, 1473 (Fed. Cir. 1998).

94. See id. 
The broad scope of federal preemption of state tort law related to the protection of federal intellectual property interests, as well as the relatively narrow scope of these alternative tort remedies, suggest that state tort law provides a relatively modest cudgel for intellectual property owners to fill the gap created by the Florida Prepaid decisions. Under the conventional view of preemption doctrine, the closer state tort law approximates federal patent and copyright law, the less likely it is to survive preemption scrutiny.

A 1993 decision by the Florida Supreme Court offers an alternative approach to preemption analysis that could bridge the gap left by the Florida Prepaid decisions. In Jacobs Wind Electric Co. $v$. Department of Transportation, ${ }^{96}$ the plaintiff alleged, in addition to the takings/inverse condemnation claim discussed earlier, ${ }^{97}$ that the Florida Department of Transportation had committed the tort of conversion by infringing the plaintiff's federal patent. In rejecting the State's preemption argument, the Florida Supreme Court reasoned that

Congress could not have intended to reserve for the federal courts exclusive jurisdiction over claims against states arising under the patent statutes because such claims could not have been brought in federal court due to Eleventh Amendment immunity. The patent statutes were intended to provide a remedy, not exclude one. ${ }^{98}$

The court emphasized that a contrary ruling would not only deny a particular remedy, but also would deny the plaintiff any "access to courts to redress its grievances. This cannot be countenanced in light of article I, section 21 of the Florida Constitution, which provides that ' $[t]$ he courts shall be open to every person for redress of any injury, and justice shall be administered without sale, denial or delay." "99

Notwithstanding that the Supreme Court cited this aspect of the Jacobs Wind case in Florida Prepaid, ${ }^{100}$ it remains to be seen whether federal courts will adopt this interpretation of federal

95. See Aronson v. Quick Point Pencil Corp., 440 U.S. 257 (1979).

96. 626 So. $2 \mathrm{~d} 1333$ (Fla. 1993).

97. See supra note 63 and accompanying text.

98. Jacobs Wind, 626 So. $2 \mathrm{~d}$ at 1336.

99. Id. at 1337.

100. 119 S. Ct. at 2209 n.9. 
preemption when they are directly confronted. In determining the scope of federal preemption, federal courts have focused upon the subject matter overlap between state and federal regimes and not on the entities subject to liability. There is little doubt that the Florida courts could not adjudicate a conversion claim of this type between private parties. Yet it seems a bit of a stretch to infer, as the Florida Supreme Court did, that the U.S. Congress intended for state courts to adjudicate patent cases against states and state entities. Nonetheless, the Florida Supreme Court's pragmatic logic bolsters the federal system and because it is limited to actions against states, does not create a direct jurisdictional conflict.

If the federal courts were to accept this view of federal preemption, intellectual property owners would have to test whether they could enforce their federal intellectual property rights in like manner in the courts of each state. Even in Florida, no court has yet held that infringement of federal intellectual property rights constitutes conversion. Although the common law of conversion has expanded over the years to encompass some forms of intangible assets, ${ }^{101}$ it has not yet been applied to interferences with intellectual property standing alone. $^{102}$ It remains to be seen whether and to what extent this tort

101. See generally RESTATEMENT (SECOND) OF TORTS, §§ 222A-249 (1965); KEETON ET AL., supra note 72, at 88-92. The tort of conversion grew out of the common law action of trover, which provided a remedy against someone who found lost goods. See RestateMENT (SECOND) OF TORTS $\S 242$ cmt. d; Hill, A New Found Haliday: The Conversion of Intangible PropertyRe-Examination of the Action of Trover and Tort of Conversion, 1972 UTAH L. REV. 511. Therefore, conversion could not apply to land because land could not be lost. Similarly, intangibles did not fit easily into the category of goods that can be lost. The tort of conversion has gradually evolved beyond the common law action of trover. The Restatement Second reflects this trend in recognizing conversion of documents establishing intangible rights, although this formulation does not extend directly to intellectual property rights. See RESTATEMENT (SECOND) OF TORTS § 242 (1965).

102. See Hurst v. Dezer/Reyes Corp., 82 F.3d 232 (8th Cir. 1996) (reversing finding of conversion of business concept when licensee continued to use the licensed name and trade dress after breaching license agreement on grounds that intangible property right was not identified with or merged in a document); Miles, Inc. v. Scripps Clinic \& Research Found., 810 F. Supp. 1091 (S.D. Cal. 1993) (holding that California had not recognized a cause of action for conversion of the intangible right to commercialize a cell line); KEETON ET AL., supra note 72, at 92. See generally Jeff C. Dodd, Rights in Information: Conversion and Misappropriation Causes of Action in Intellectual Property 
theory could be used to obtain remedies for patent and copyright infringement by the state. The larger limitation of this approach would appear to be whether other states analyze preemption and open up their courts in this manner. One Texas court has already expressed some doubts. ${ }^{103}$ Tort causes of action, as well as the interpretation of the scope of federal preemption and the extent of waiver of sovereign immunity, vary across states. Nonetheless, the Florida Supreme Court's pragmatic interpretations of federal preemption doctrine and the tort of conversion afford some promise that intellectual property owners have reasonably effective remedies for state infringement of their federal rights in at least one state.

\section{c. state intellectual property law claims}

Even though intellectual property owners cannot sue states for infringing their federal intellectual property rights in state court, ${ }^{104}$ they may be able to recover in state courts for state violations of state intellectual property laws. Because of the preemptive sweep of federal copyright and patent law, states cannot duplicate the protection afforded by these regimes under state law. Nonetheless, they afford some room for alternative means of protecting innovation. All states have trade secret laws ${ }^{105}$ which afford substantial protection for

Cases, 32 Hous. L. REV. 459, 498 (1995) (concluding that courts "now protect information that touches some document, giving it an independently verifiable existence, even though the information is not necessarily merged in or identified with that document"); Val D. Ricks, Comment, The Conversion of Intangible Property: Bursting the Ancient Trover Bottle with New Wine, 1991 BYU L. REV. 1681, 1703-04 (1991) (listing cases in which conversion has been recognized for intangibles).

103. See A.C. Aukerman Co. v. Texas, 902 S.W.2d 576, 578-79 (Tex. Ct. App. 1995).

104. 28 U.S.C. $§ 1338$ (a) (1994) provides that federal district courts shall have original and exclusive jurisdiction over any civil action arising under any act of Congress relating to patents, plant variety protection, and copyrights. Therefore, intellectual property owners may not assert claims under these statutes in state court. Furthermore, under the Supreme Court's decision in Alden v. Maine, 527 U.S. 706 (1999), states have sovereign immunity against suits in their own courts for violations of federal law. Therefore, Congress cannot subject a state to liability for infringing federal intellectual property law in its own courts without the state's consent.

105. The Supreme Court has ruled that federal patent law does not preempt state trade secret law. See Kewanee Oil Co. v. Bicron Corp., 416 U.S. 470 (1974); Warrington Assocs., Inc. v. Real-Time Eng'g Sys., Inc., 522 F. Supp 
innovation. Forty states have adopted some form of the Uniform Trade Secrets Act. ${ }^{106}$ The remaining states rely primarily upon the principles reflected in the Restatement of Torts or the more comprehensive and recent formulation in the Restatement of Unfair Competition. ${ }^{107}$ Unlike the federal patent and copyright regimes, federal trademark law does not generally preempt analogous state law. ${ }^{108}$ All states have legislation providing for the registration and protection of trademarks. ${ }^{109}$ Numerous states protect the right of publicity, a relatively recently developed intellectual property right which prevents others from appropriating a person's identity, image, or persona for commercial gain. ${ }^{110}$

As with tort actions, a claimant cannot sue the state even under its own intellectual property laws unless the state has waived its sovereign immunity. Where a state has waived its sovereign immunity through an open-ended statute ${ }^{111}$ and does not provide exceptions for

367 (N.D. Ill. 1981).

106. See JAMES POOLEY, TRADE SECRETS § 2.03[7](a), at 2-27 n.51 (1997) (collecting state codes).

107. See id. § 2.02[3] (explaining evolution of the Restatement relating to trade secret law).

108. See 15 U.S.C. $\S \S 1065,1115$ (b)(5) (1999) (referring to the continued effect of state law); Richard A. De Sevo, Antidilution Laws: The Unresolved Dilemma of Preemption Under the Lanham Act, 84 TRADEMARK REP. 300, 301-04 (1994). But cf. Three Blind Mice Designs Co. v. Cyrk Inc., 892 F. Supp. 303 (D. Mass. 1995) (preempting state antidilution statute to the extent that it seeks to regulate competitive goods). The recently enacted federal antidilution law, 15 U.S.C. $\S 43$ (c)(3), allows state antidilution laws to continue in force but grants owners of federally registered marks immunity from suit under such state laws. See H.R. REP. No. 104-374 (accompanying H.R. 1295) (1995), reprinted in 1995 U.S.C.C.A.N. 1033. A number of cases hold that state protection against confusion and passing off is not preempted by federal copyright law. See, e.g., Donald Frederick Evans \& Assocs., Inc. v. Continental Homes, Inc., 785 F.2d 897 (11th Cir. 1986).

109. Substantially all of these enactments follow the Model State Trademark Bill. See generally RESTATEMENT (THIRD) OF UNFAIR COMPETITION $\S 9$ statutory note (1995) (collecting state statutes); J. THOMAS MCCARTHY, TRADEMARKS AND UNFAIR COMPETITION (4th ed. 1996).

110. See Restatement (THIRD) OF UNFAIR COMPETition $\S \S 46-49$; J. THOMAS MCCARTHY, THE RIGHTS OF PUBLICITY AND PRIVACY (1937). Federal intellectual property law does not generally preempt state protection of the right of publicity. See Zacchini v. Scripps-Howard Broad. Co., 433 U.S. 562 (1977).

111. See supra text accompanying note 82 . 
state intellectual property statutes and common law, it can be inferred that the state permits claimants to pursue whatever legal or administrative process that the state has established for seeking redress. ${ }^{112}$ Where a state waives sovereign immunity through a closedended statute ${ }^{113}$ and has not expressly authorized suits against the state for violations of its intellectual property statutes, courts may hold that the state cannot be sued for violations of its own intellectual property laws. ${ }^{114}$ It can be argued, however, that trademark, trade secret, and right of publicity causes of action grow out of tort theories of recovery. ${ }^{115}$ To date, there have been relatively few reported cases determining whether states have waived immunity to liability under their own intellectual property statutes.

Even if actionable against the state, state intellectual property law does not directly compensate for state infringement of federal patent and copyright law. Depending upon the circumstances, however, they may, in concert with other tort remedies discussed earlier, afford intellectual property owners effective substitutes for federal patent and copyright protections. For example, a company regularly doing business with the state may elect to rely more heavily upon trade secret protection if federal patent protection is not effective against the state. ${ }^{116}$

112. See, e.g., Management Ass'n, Inc. v. Board of Regents of N. Ill. Univ., 618 N.E.2d 694, $707-08$ (IIl. App. Ct. 1993) (holding that state may be sued in Court of Claims for alleged trade secret violations).

113. See supra text accompanying note 81 .

114. See, e.g., Texas A \& M Univ. Sys. v. University Book Store, Inc., 683 S.W.2d 140 (Tex. Ct. App. 1985) (holding that a suit to cancel the certificate of registration of five service marks issued by the secretary of state to Texas A \& $M$ University was an attempt to control valid and proper state action that was not maintainable without the state's consent).

115. Trade secret protection was part of the first RESTATEMENT OF TORTS $\S \S$ 757-59 (1939). Trademark law comprises various aspects of unfair competition, unjust enrichment, passing off, and various other tort law concepts, see RESTATEMENT (THIRD) OF UNFAIR COMPETITION § 9 cmts. b \& c (1995), although the antidilution provisions reflect more of a property orientation. See Peter S. MENEll, Intellectual Property: General Theories, INTERNATIONAL ENCYCLOPEDIA OF LAW AND ECONOMICS (2000). The right of publicity also has tort roots, growing out of defamation, privacy, and false advertising principles. See MCCARTHY, supra note 105, at ch. 1 .

116. Cf. MERGES ET AL., supra note 84; David D. Friedman et al., Some Economics of Trade Secret Law, 5 J. ECON. PERSPECTIVES 61 (1991); Richard C. Levin et al., Appropriating the Returns from Industrial Research and De- 


\section{d. contract claims}

Intellectual property owners may have a contractual basis for seeking damages and other remedies from states. States often contract for products and services that involve intellectual property rights. A state agency may agree to restrictions on the use and distribution of products embodying intellectual property as part of a licensing agreement or some other contractual nexus. Software vendors, for example, commonly distribute computer programs through end-user licensing agreements. ${ }^{17}$ Intellectual property owners who present proposals to state agencies may be able to draw upon principles of implied contract and confidential relationship law. ${ }^{118}$ Intellectual property owners may be able to enforce these provisions through state court contract actions.

As with tort claims, intellectual property owners can bring contract claims against the state only if the state has waived its sovereign immunity and authorized suit for such claims. Many states expressly waive their sovereign immunity for contractual liability through their constitution $^{119}$ or by state statute. ${ }^{120}$ In addition, many state courts

velopment, in BROOKINGS PAPERS ON ECON. ACTIVITY 783-831 (1987) (noting the importance of trade secrets relative to patent protection in many industries).

117. See generally MARK A. LEMLEY ET AL., SOFTWARE AND INTERNET LAW ch. 1 (2000).

118. See Lionel S. Sobel, The Law of Ideas, Revisited, 1 UCLA ENT. L. REV. 9 (1994).

119. See GA. CONST. art. I, § 2, ๆ IX(c); LA. ConsT. art. 12, § 10(A).

120. See AlASKa STAT. $\S 09.50 .250$ (Michie 1999); ARK. CODE ANN. $\S \S$ 19-10-201 to 210 (Michie 1999); CAL. GoV'T CODE $\S 884$ (West 1999); CONN. GEN. STAT. § 4-61(a) (1999); GA. CODE ANN. § 50-21-1 (1999); HAW. REV. STAT. § 661-1 (1999); 705 ILL. COMP. STAT. 505/8 (West 1999); IND. CODE § 34-4-16-1.1 (1999); KY. REV. STAT. ANN. § 45A.245 (Michie 1999); ME. REV. STAT. ANN. tit. 5, § 1510-A (West 1999); MD. CODE ANN., STATE GoV'T § 12-201(a) (1999); MINN. STAT. § 3.751 (1999); NEV. REV. STAT. § 41.031 (1999); N.H. REV. STAT. ANN. § 491:8 (1999); N.M. STAT. ANN. § 37-1-23 (Michie 1999); N.Y. CT. CL. ACT $\S 8$ (McKinney 1999); N.D. CENT. CODE § 32-12-02 (1999); OHIO REV. CODE ANN. § 2743.02(A)(1) (West 1999); OR. REV. STAT. § 30.320 (1999); 72 PA. CONS. STAT. $§ 4651-1$ (1999); R.I. GEN. LAWS $\S 37-13.1-1$ (1999); S.D. CODIFIED LAWS $\$ \S 21-32-2,-10$ (Michie 1999); TENN. CODE ANN. § 9-8-307(a)(1)(L) (1999); UTAH CODE ANN. § 63-30-5 (1999); WASH. REV. CODE § 4.92 .010 (1999); W. VA. CODE $\S \S 14-2-4,-13$ (1999); WYO. STAT. ANN. § 1-39-104 (Michie 1999); see also Parsa v. State, 474 N.E.2d 235 (N.Y. 1984) (charging contracting party with knowledge of statutes regulating the state's power to enter into contracts). 
infer that a state waives its sovereign immunity for contractual liability by validly entering into a contract. ${ }^{121}$ Some state courts have abolished sovereign immunity for contractual liability altogether. ${ }^{122}$

Only a few states bar suits in state court for breach of contract claims against the state. Vermont does not apply its waiver of tort liability to "damages caused by the fiscal operations of any state officer or department." Wisconsin requires that contract claims against the state be presented to a Claims Board which can propose to the legislature that a private bill for compensation be enacted. ${ }^{124}$ The Texas Supreme Court recently reaffirmed the vitality of sovereign immunity from contractual liability in the Lone Star State. ${ }^{125}$

Even though substantially all states allow contract actions against the state to be heard in state court, some contractual provisions that overlap substantially with federal intellectual property rights may be preempted. Contractual provisions that do not implicate the policies of the federal intellectual property system easily survive scrutiny, even if a state tribunal must assess the validity of a

121. See, e.g., State Highway Dep't v. Milton Constr. Co., 586 So. $2 \mathrm{~d} 872$, 875 (Ala. 1991); Souza \& McCue Constr. Co. v. Superior Court, 57 Cal. 2d 508, 370 P.2d 338, 20 Cal. Rptr. 634 (1962); Ace Flying Serv., Inc. v. Colorado Dep't of Agric., 314 P.2d 278, 280 (Colo. 1957); George \& Lynch, Inc. v. State, 197 A.2d 734, 736 (Del. 1964); Pan-Am Tobacco Corp. v. Department of Corrections, 471 So. 2d 4, 5 (Fla. 1985); Regents of Univ. Sys. v. Blanton, 176 S.E. 673, 675 (Ga. Ct. App. 1934); Grant Constr. Co. v. Burns, 443 P.2d 1005, 1010 (Idaho 1968); Kersten Co. v. Department of Soc. Servs., 207 N.W.2d 117, 120 (lowa 1973); J.A. Sullivan Corp. v. Commonwealth, 494 N.E.2d 374, 377 (Mass. 1986); Hersey Gravel Co. v. State, 9 N.W.2d 567, 569 (Mich. 1943); State Highway Comm'n v. Wunderlich, 11 So. 2d 437, 438 (Miss. 1943); V.S. DiCarlo Constr. Co. v. State, 485 S.W.2d 52, 55 (Mo. 1972); Meens v. State Bd. of Educ., 267 P.2d 981, 984-85 (Mont. 1954); Smith v. State, 222 S.E.2d 412, 423-24 (N.C. 1976); State Bd. of Pub. Affairs v. Principal Funding Corp., 542 P.2d 503, 505-06 (Okla. 1975); Kinsey Constr. Co. v. South Carolina Dep't of Mental Health, 249 S.E.2d 900, 903 (S.C. 1978); Wiecking v. Allied Med. Supply Corp., 391 S.E.2d 258, 261 (Va. 1990).

122. See Stone v. Arizona Highway Comm'n, 381 P.2d 107, 109 (Ariz. 1963); Brown v. Wichita State Univ., 540 P.2d 66, 84-86 (Kan. 1975); Todd v. Board of Educ. Lands \& Funds, 48 N.W.2d 706, 710 (Neb. 1951); P. T. \& L. Constr. Co. v. Commissioner, Dep't of Transp., 288 A.2d 574, 578 (N.J. 1972). 123. VT. STAT. ANN. tit. $12, \S 5601$ (1999).

124. See WIS. STAT. § 16.007 (1999).

125. See Federal Sign v. Texas S. Univ., 951 S.W.2d 401 (Tex. 1997). 
federal intellectual property right in the process of adjudicating the contract dispute. ${ }^{126}$ Those contractual restrictions that undermine the policies of the federal intellectual property system are preempted. ${ }^{127}$ Courts have struggled to develop clear principles with regard to the viability of software licensing agreements that supplant some of copyright's default rules. ${ }^{128}$ This challenge has been exacerbated by the fact that computer software vendors and Internet retailers have increasingly used shrinkwrap and clickwrap license agreements in transacting. ${ }^{129}$ The National Conference of Commissioners on Uniform State Laws recently approved the Uniform Computer Information Transactions Act (UCITA), which generally permits parties to enforce shrinkwrap agreements. Under the Supremacy Clause of the U.S. Constitution, however, the enforceability of contracts pursuant

126. See, e.g., Intermedics Infusaid, Inc. v. Regents of the Univ. of Minn., 804 F.2d 129, 132-33 (Fed. Cir. 1986) (" $[\mathrm{T}]$ here are no policies reflected in acts of Congress which require that the federal courts enjoin ... a state court contract suit seeking royalties payable under a patent license wherein the state court is or could be asked by the defendant to rule on the validity of the patent."); Smith, 578 F. Supp. at 1307 (holding that breach of contract and confidential relationship claims are not preempted by copyright law), aff'd, 738 F.2d 419 (2d Cir. 1984).

127. See, e.g., Lear, Inc. v. Adkins, 395 U.S. 653 (1969) (invalidating contractual provision prohibiting licensee to challenge the validity of patent); Brulotte v. Thys Co., 379 U.S. 29 (1964) (holding unenforceable patent licensed in agreement that extends beyond the patent's term).

128. Compare Step-Saver Data Sys. v. Wyse Tech., 939 F.2d 91 (3d Cir. 1991) (holding that disclaimer of warranty and limitation of remedies terms in a shrinkwrap license agreement did not become part of parties' agreement), and Vault Corp. v. Quaid Software Ltd., 847 F.2d 255 (5th Cir. 1988) (holding that a provision in the license agreement of a producer of anticopying software which prohibited decompilation or disassembly of its program was unenforceable), with ProCD, Inc. v. Zeidenberg, 86 F.3d 1447 (7th Cir. 1996) (taking a narrow view of federal copyright preemption in enforcing shrinkwrap license agreements that prohibited the copying of uncopyrightable material), and Hill v. Gateway 2000, Inc., 105 F.3d 1147 (7th Cir. 1997) (holding that terms sent to buyer in the box in which the computer was shipped, including an arbitration clause, were binding on the buyer). See generally Mark A. Lemley, Beyond Preemption: The Law and Policy of Intellectual Property Licensing, 87 CAL. L. REV. 111, 142 (1999) ("[Courts must] attempt to figure out whether each particular provision in the Copyright Act is merely a default rule that the parties are free to ignore, or whether it instead reflects a part of the balance of interests in federal policy that should not be upset.").

129. See Novell, Inc. v. Network Trade Ctr., Inc., 25 F. Supp. 2d 1218 (D. Utah 1997). 
to state laws remain subject to the preemptive force of copyright and other federal laws.

As this review of the vast and complex legal landscape reveals, the striking down of the intellectual property remedy clarification acts does not exempt states from liability for infringing intellectual property rights. Federal law continues to provide prospective remedies to enjoin infringement of federal intellectual property rights. In addition, intellectual property owners can recover monetary damages from state employees who violate federal intellectual property rights. Furthermore, state remedies for inverse condemnation and violations of tort, state intellectual property, and contract laws create a variety of opportunities for intellectual property owners to pursue retrospective monetary damages. The amount of damages available through these forms of recourse may well be less than the remedies under federal patent and copyright law. In addition, many of these state law theories have not been widely tested in the context of intellectual property rights. The lack of uniformity and novel aspects of these avenues of legal and administrative recourse will complicate the lives of intellectual property owners whose rights are infringed by states and state officials. Intellectual property owners with smaller stakes may well decide that these remedies are not worth the effort.

\section{B. Social and Bureaucratic Constraints on State Infringement of Intellectual Property Rights}

Even if the law afforded state and state actors complete immunity from liability for infringement of federal intellectual property rights, social and bureaucratic constraints, market restraints, and political checks would significantly regulate state infringement activity. ${ }^{130}$ These various constraints are often interrelated. In addition, they interact with the legal constraints discussed previously. It is worthwhile, however, to explore each of these governance regimes individually so as to better understand the implications of the Florida Prepaid decisions. This section focuses on the role of social norms and bureaucratic constraints in regulating state infringement. The treatment of each regulatory institution will discuss some of the

130. $C f$. ROBERT C. ELLICKSON, ORDER WiTHOUT LAW: HOW NEIGHBORS SETTLE DISPUTES (1991) (emphasizing the role of social norms in regulating human behavior). 
feedback and interactive effects among the various governance systems.

\section{Distinctive characteristics of public administration}

Economic analysis of legal rules often proceeds from the premise that entities and actors will maximize their economic self-interest. In such a framework, we would predict that entities and actors will infringe intellectual property rights if there are no remedies to penalize such behavior and such infringement promotes their economic self-interest. Therefore, assuming that there were no effective remedies against state infringement, then state governments and their employees would be prone to infringe federal intellectual property rights. This perspective, however, overlooks the role of social norms and other institutional constraints upon the behavior of the relevant entities and actors. State entities and employees do not typically approach their jobs from a narrowly self-interested perspective. Furthermore, they operate within complex institutional structures that regulate the actions of both the entities and the employees.

The environment in which state entities and employees operate differs markedly from the private sector. ${ }^{131}$ With regard to the propensity to infringe intellectual property rights, the following characteristics have most relevance: the nature of the activities conducted, the goals of the organization, the ethics and integrity of decisionmakers, the extent to which employee conduct is constrained by rules and policies, the openness and permeability of the working environment, the accountability of employees, incentives for employee advancement, and the profile of the workforce.

Nature of Activities. State agencies and entities perform a wide range of functions, many of which differ in significant ways from private sector enterprises. State agencies and organizations regulate private activities that cause adverse effects-such as pollution, crime, and health and safety exposures-provide various social services, assist markets in functioning by licensing and regulating activities, offer education, health care, and other services, and provide and maintain basic infrastructure such as roads and

131. See Hal G. RaINey, Understanding \& Managing PubliC ORGANIZATIONS 73-74 (2d ed. 1997) (table summarizing distinctive characteristics of public management of organizations). 
transportation. Because of the differences among these functions, state entities differ significantly in the ways in which they are organized and the compositions of their work forces.

Goals. In view of the nature of these activities and the essential public-regarding qualities of government, state entities, unlike most private sector enterprises, do not seek to maximize profits. Rather they typically pursue multiple, sometimes competing, goals. For example, state police and highway patrols seek to protect public safety, prevent crime, and respect individual rights, as well as conserve public resources. ${ }^{132}$ Environmental agencies are instructed to both conserve resources and develop them. ${ }^{133}$ State entities, therefore, tend to pursue more multifaceted, ambiguous, and conflicting goals than private corporations. ${ }^{134}$

Ethics and Integrity of Decisionmakers. The public holds government entities and officials to higher standards of fairness, honesty, openness, and accountability than private actors. As a reflection of government officials' quasi-fiduciary responsibility to protect the public trust, the American Society for Public Administration stresses, in its code of ethics, the need for public administrators to "respect, support, study, and when necessary, work to improve federal and state constitutions, and other laws which define the relationships among public agencies, employees, clients, and all citizens."

Rule-Oriented Work Environment. State government organizations tend to be bureaucratic and rule driven. This is partly attributable to the large size of many public entities, but also reflects legal constraints and oversight by legislative and executive bodies and civil service and union rules.

132. See Mark H. MoOre, Police Leadership: The Impossible Dream, reprinted in IMPOSSIBLE JOBS IN PUBLIC MANAGEMENT (Erwin C. Hargrove \& John C. Glidewell eds., 1990).

133. See Aaron B. WildaVSKy, SPEAKIng Truth to Power 215 (1979).

134. See THEODORE J. LOWI, THE END OF LIBERALISM (1979); RAINEY, supra note 126, at 128-30; HAROLD SEIDMAN \& ROBERT GILMOUR, POLITICS, POSITION, AND POWER (1986).

135. AMERICAN SOCIETY FOR PUBLIC ADMINISTRATION, CODE OF ETHICS AND IMPLEMENTATION GUIDELINES (1984); see Donald J. Maletz, The Place of Constitutionalism in the Education of Public Administrators, 23 ADMIN. \& SoC'Y 374 (1991); Ralph C. Chandler, The Problem of Moral Reasoning in American Public Administration: The Case for a Code of Ethics, 43 PUB. ADMIN. REV. 32 (1983). 
Openness and Permeability of Working Environment. Government entities conduct their activities through public processes. Many important decisions are made through formal, on the record, processes in which citizens have the opportunity to participate through submitting comments and attending public hearings. In the postWatergate era, most states adopted far-reaching freedom of information laws that afford citizens and the media wide access to public records. ${ }^{136}$ The media, agency clients and constituents, and interested citizens can gain access to much of what public entities do. By contrast, the decision-making processes of most private corporations are shielded from public view. Many companies consider information developed within their factories and offices to be trade secrets.

Accountability of State Employees. Public employees are typically accountable to a wide range of constituencies. They fall under the governance of executive and legislative oversight bodies, as well as other governing authorities. For example, the University of California is governed by a Board of Regents selected by the governor. Its budget is determined by the legislature and approved by the governor. The performance of public entities is scrutinized by various external constituencies, including the media, interest groups, and others.

Incentives for Advancement. The rigid bureaucratic structure of public entities-reflecting the rule-oriented work environment and civil service and union influences-constrain the ways in which employees may advance within the public sector employment hierarchy. Because of the multifaceted, vague, and sometimes ambiguous goals of government entities, public organizations do not have the same ability as private profit-centered enterprises to develop clear performance measures. As a result, they tend to evaluate employee performance based on adherence to procedure and compliance with rules. ${ }^{137}$

136. See generally JUSTIN B. FRANKLIN \& ROBERT E. BOUCHARD, THE FREEDOM OF INFORMATION AND PRIVACY ACTS (2d ed. 1999) (compiling public information acts from each state).

137. See Allen H. Barton, A Diagnosis of Bureaucratic Maladies, in MAKING BUREAUCRACIES WORK (C.H. Weiss \& A.H. Barton eds., 1980); Robert A. DAHL \& CHARLES E. LINDBLOOM, POLITICS, ECONOMICS, AND Welfare (1953); Hal G. Rainey, Public Agencies and Private Firms: Incentive Structures, Goals, and Individual Roles, 15 ADMIN. \& SOC'Y 207 (1983). 
Profile of the Public Sector Workforce. The financial rewards available in public employment are constrained by civil service and legislative pay scales. The civil service system and the high rate of unionization in the public sector typically afford public employees better job security than those in the private sector. Not surprisingly, studies reveal that public employment attracts workers seeking this balance of job attributes: public employees place a higher value on job security, ${ }^{138}$ but a lower value on financial rewards, ${ }^{139}$ than their counterparts in the private sector. Similarly, the public sector tends to attract employees who place higher a value on intrinsic rewards, self-sacrifice, and public service than workers in the private sector. ${ }^{140}$

2. Implications for state infringement of federal intellectual property rights

These distinctive characteristics of state government suggest that state entities are unlikely to adopt policies encouraging, permitting, or excusing infringement of federal intellectual property rights. The Florida Prepaid decisions do not condone state infringement; rather, they limit the ways in which intellectual property owners can enforce their rights against states. But it is unlikely, given our organizational culture and institutional constraints, that states or state organizations will embark on policies that conflict with federal law. State entities generally require that their employees adhere to federal and state law in carrying out their responsibilities. Many also have specific policies relating to intellectual property. For example, the University of California has specific policies and guidelines designed to ensure that employees do not violate federal intellectual property law. ${ }^{141}$

Nor are state officials or employees likely to infringe intellectual property rights. The public sector attracts workers who are disinclined to violate the law. Moreover, state employees operate within

138. See RAINEY, supra note 131 , at 213-15.

139. See Mak Khojasteh, Motivating the Private vs. Public Sector Managers, 22 PUB. PERSONNEL MGMT. 391 (1993); Rainey, supra note 132, at 207.

140. See RAINEY, supra note 131, at 216-18; Steven Kelman, "Public Choice" and Public Spirit, 87 PUB. INTEREST 80 (Spring 1987) (arguing that public employees reflect a norm of public spiritedness).

141. See, e.g., University of California Policy and Guidelines on the Reproduction of Copyrighted Materials for Teaching and Research (visited Mar. 30, 2000) <http://www.ucop.edu/ucophome/uwnews/copyrep.html>. 
highly structured and open environments in which their activities can be easily scrutinized by supervisory officials as well as the public. Furthermore, they cannot expect to profit in any significant way from infringing activities-either through direct commercial activities or improving the bottom line for their division-because government employees do not have equity stakes in their operations and state agencies do not budget within a profit-maximizing framework. By engaging in significant infringing activities, public employees open themselves up to being sued in their personal capacity for monetary damages and expose their employers to injunctions and embarrassing public scrutiny. Although the public employees might be able to get indemnification and representation by the public entity, they jeopardize their job security, something that public employees generally value highly. Therefore, they have little if anything to gain, and a lot to lose, from infringing federal intellectual property rights.

This is not to say that state entities and employees will never infringe federal intellectual property rights. State entities and employees may unintentionally infringe such rights, but it is likely that they will be responsive to the interested parties in many circumstances. In some cases, state entities may not invoke state sovereignty. ${ }^{142}$ Furthermore, as noted in the prior section, intellectual property owners are not without legal recourse. Even in the absence of these disincentives, the nature of public entities and the employees attracted to them suggest that state infringement, to the extent it occurs, is likely to be unintentional and episodic in most areas of state activity.

One area in which social and bureaucratic constraints will probably have less of a dampening effect on state infringement relates to state university research. ${ }^{143}$. University laboratories have produced many of the breakthroughs on which the biotechnology and digital technology industries are based. A number of developments have drawn universities into the commercial sphere, which inevitably raises the potential for infringement of intellectual property rights.

142. See, e.g., Ringling Bros. Barnum \& Bailey Combined Shows, Inc. v. Utah Div. of Travel Dev., 955 F. Supp. 605 (E.D. Va. 1997) (sovereign immunity not invoked), aff'd, 170 F.3d 449 (4th Cir. 1999), cert. denied, $120 \mathrm{~S}$. Ct. 286 (1999).

143. See Robert G. Bone, From Property to Contract: The Eleventh Amendment and University-Private Sector Intellectual Property Relationships, 33 LOY. L.A. L. REV. 1467 (2000). 
First, many state legislatures have gradually decreased the percentage of the universities' budgets funded through state tax revenues. Second, the growth rate of federal funding of university research has gradually declined over the past decade. ${ }^{144}$ Third, the federal government, which provides funding for a substantial portion of university research, now permits universities (and other nonprofit organizations) to retain title to inventions funded from federal sources. ${ }^{145}$ Fourth, government funding for university research has vacillated over the years, motivating universities to expand their portfolio of funding sources. ${ }^{146}$ As a result, a number of leading state universities have developed patent licensing offices. ${ }^{147}$

Lastly, university researchers and professors have increasingly pursued opportunities to commercialize their research. The advent and proliferation of venture financing has enabled university researchers to start their own companies, leading many research pioneers to spin off university research projects into private commercial ventures in which the university researcher is a substantial stakeholder. These opportunities have changed the culture of

144. See NATIONAL SCIENCE BOARD, SCIENCE AND ENGINEERING INDICATORS: 1998 chs. 4-5.

145. See Bayh-Dole Act, Pub. L. No. 96-517, § 6(a), 94 Stat. 3015, 3019-28 (1980) (codified as amended at 34 U.S.C. $\$ \S 200-212$ (1994)). See generally Rebecca S. Eisenberg, Public Research and Private Development: Patents and Technology Transfer in Government-Sponsored Research, 82 VA. L. REV. 1663 (1996).

146. See NATIONAL SCIENCE BOARD, supra note 144, at ch. 5 (noting that for 1995, public academic institutions received $7 \%$ of research and development funding from industry, $10 \%$ from state and local funds, $23 \%$ from institutional funds, and $54 \%$ from the federal government and that over the past two decades, the federal share of support has declined, and the industry and institutional shares have increased).

147. See, e.g., Office of Technology Transfer, University of California (visited Apr. 1, 2000) <http://www.ucop.edu/ott> (providing descriptions of technologies available for licensing from the University of California campuses). See generally NATIONAL SCIENCE BOARD, supra note 139, at ch. 5 (noting a sevenfold rise in the number of academic patents received annually between the mid-1970s and the mid-1990s to more than 1800 in 1995 and that public universities outpace private universities in obtaining patents); R. HENDERSON ET AL., Universities AS A SOURCE OF COMMERCIAL TECHNOLOGY: A DETAILED ANALYSIS OF UNIVERSITY PATENTING 1965-88 (National Bureau of Econ. Research Working Paper No. 5068, 1995). 
university research laboratories. ${ }^{148}$ Many university scientists entering public universities today seek both academic recognition and entrepreneurial opportunity.

State university researchers and professors have not typically fit the traditional civil servant mold, but their traditional focus upon academic recognition and basic scientific breakthroughs minimized the risk that they would infringe or cause harm to the intellectual property rights of others. As state universities and their researchers look increasingly to the market for organizational and personal returns, the risks to intellectual property right owners rise accordingly. Not surprisingly, state universities are the one type of state entity that has been involved in numerous and substantial intellectual property disputes. ${ }^{149}$

The implications of these trends are further complicated by the in-flow of industry funds into state university research programs. ${ }^{150}$

148. See Rebecca S. Eisenberg, Proprietary Rights and the Norms of Science in Biotechnology Research, 97 YALE L.J. 177 (1987).

149. See, e.g., Genentech, Inc. v. Regents, 143 F.3d 1446 (Fed. Cir. 1998), judgment vacated and remanded, 119 S. Ct. 2388 (1999); In re Regents, Misc. No. 425, 1995 U.S. App. LEXIS 8032 (Fed. Cir. Mar. 21, 1995); Synbiotics Corp. v. Regents, No. 93-1253, 94-1079, 1994 U.S. App. LEXIS 23902 (Fed. Cir. Aug. 29, 1994); In re Regents, 964 F.2d 1128 (Fed. Cir. 1992); New Star Lasers, Inc. v. Regents, No. CIV. S-99-428, 1999 U.S. Dist. LEXIS 13411 (E.D. Cal. Aug. 26, 1999); Kucharczyk v. Regents, 48 F. Supp. $2 d 964$ (N.D. Cal. 1999); Regents v. Veterinary Ctrs. of America, Inc., No. 1262, 1999 U.S. Dist. LEXIS 1741 (J.P.M.L. Feb. 19, 1999); Candela Corp. v. Regents, 976 F. Supp. 90 (D. Mass. 1997); Regents v. Oncor, Inc., No. C-95-3084-VRW, 1997 U.S. Dist. LEXIS 15068 (N.D. Cal. Aug. 19, 1997); Dieter v. Regents, 963 F. Supp. 908 (E.D. Cal. 1997); Brown v. Regents, 866 F. Supp. 439 (N.D. Cal. 1994); Unix Sys. Labs., Inc. v. Berkeley Software Design, Inc., 832 F. Supp. 790 (D.N.J. 1993); Ciba-Geigy Corp. v. Alza Corp., No. 91-5286, 1993 U.S. Dist. LEXIS 3971 (D.N.J. Mar. 25, 1993).

150. See Donald S. ChISUM ET AL., PRINCIPLES OF PATENT LAW 1026-29 (1998); NATIONAL SCIENCE BOARD, supra note 139, at ch. 5; Richard C. Atkinson, The Future Arrives First in California, IssUES IN SCI. \& TECH. 45, 4648 (Winter 1999-2000) (describing the University of California's IndustryUniversity Cooperative Research Program); William L. Baldwin, The U.S. Research University and the Joint Venture: Evolution of an Institution, 11 REV. INDUST. ORG. 629 (1996); David Blumenthal et al., Industrial Support of University Research in Biotechnology, 231 SCIENCE 242, 244 (1986) (observing that nearly half of all biotechnology firms support university research through university-industry research programs); W.M. Cohen et al., Industry and the Academy: Uneasy Partners in the Cause of Technological Advance, in 
Many of these programs create partnerships which enable donor firms to commercialize some of the research developed. This raises complex questions about whether the research is in fact public.

\section{Market Responses to the Risks of State Infringement of Intellectual Property Rights}

Even apart from legal action, intellectual property owners can engage in a variety of self-help responses to the risk of state infringement of intellectual property rights. They can take advantage of their economic clout directly in their dealings with states and state entities by getting involved in state and federal politics.

With regard to market responses, intellectual property owners have a wide range of relationships with the states. At one extreme, they engage in direct, detailed negotiations for products and services customized to the states needs such as standardized tests for state employees, training films, and customized data processing software. Similarly, many state universities now enter into long-term contractual relationships in the form of industry-university research consortia and funding agreements. At the other extreme, the state can gain access to proprietary technology without any formal contractual relationship. For example, a state university professor can learn of a proprietary technology by perusing issued patents or scientific publications. Between these extremes, states acquire technology products (such as word processing software) through the retail marketplace.

Intellectual property owners can protect their technology from improper appropriation by legal strangers-those with whom they are not in a contractual relationship-by limiting access to their works through either formal trade secrecy ${ }^{151}$ or encryption. If state entities cannot gain access to a work, then they cannot commandeer it. These strategies can have significant drawbacks. By relying upon trade secret, rather than patent protection, an inventor has no protection against someone who independently develops the invention. In addition, the inventor might even lose the right to practice his or her

CHALLENGE TO THE RESEARCH UNIVERSITY (Roger Noll ed., 1998).

151. In fact, apart from the pharmaceutical industry, most companies rely more heavily upon trade secret protection than patent protection to discourage unauthorized appropriation of their technology. See Levin et al., supra note 116 , at 783 . 
invention if another company obtains a patent. From society's standpoint, trade secrecy can hinder the progress of research and development by limiting the diffusion of new knowledge. By contrast, the patent system promotes disclosure of innovation by requiring that applicants adequately disclose and enable their invention. Encryption can limit the utility of a work by constraining the manner in which the work can be used and customized.

Where an intellectual property owner has a formal, detailed contractual relationship with a state, the intellectual property owner can protect against infringement through the agreement. In substantially all states, such agreements will be enforceable in state court. The intellectual property owner could also insist upon waiver of state sovereign immunity to federal lawsuits, although such waivers might require legislative authorization in some states. The key determinants will be the respective bargaining power of the parties and the extent to which state law limits the terms of such contracts.

Focusing on the state university context, which appears to be the area of greatest concern for infringement, the formation of industryuniversity research agreements provides intellectual property owners with more concentrated leverage for insisting upon protection from infringement. State universities receive approximately seven percent of their research funding, on average, from private sources. ${ }^{152}$ These relationships typically involve shared and ongoing governance between universities and private sector partners. ${ }^{153}$

When the state acquires access to technology through the retail marketplace, intellectual property can augment their federal intellectual property protections through contractual limitations on infringement. The software industry has increasingly relied on these mechanisms through the use of shrinkwrap and clickwrap licensing

152. See NATIONAL SCIENCE BOARD, supra note 144, at ch. 5 .

153. The Government-University-Industry Research Roundtable, which is sponsored by the National Academy of Sciences, the National Academy of Engineering, and the Institute of Medicine, oversees approximately a dozen research consortia between universities and industry. The Roundtable "addresses a wide array of concerns including nurturing science and engineering talent, financing research facilities, promoting multidisciplinary research and education, and enhancing federal-state cooperation in science and technology." The Government-University-Industry Research Roundtable (visited Mar. 26, 2000) <http://www4.nationalacademies.org/pd/guirr.nsf>. 
agreements. Although the enforceability of these contracts has not been decisively resolved, ${ }^{154}$ intellectual property owners will at a minimum get their day in state court. Substantially all states have consented to suit for breach of contract.

\section{Political Constraints on State Infringement of Federal Intellectual Property Rights}

In addition to market solutions, intellectual property owners can deter state infringement of intellectual property rights through political efforts. As a class, intellectual property owners have tremendous political clout. Entertainment industries have long been involved in national and state politics. ${ }^{155}$ New technology companies are among the most successful and wealthy enterprises in the United States. Over the past two decades, they have become increasingly involved in political affairs. American technology companies initially mobilized in the early 1980s in an effort to push for stronger protection in intellectual property laws abroad. ${ }^{156}$ More recently, high-technology companies ${ }^{157}$ and their trade associations ${ }^{158}$ have

154. See supra Part I.A.2.d.

155. The Motion Picture Association of America (MPAA), representing the seven largest film production and distribution companies, and the Recording Industry Association of America (RIAA), representing the leading record producers, have long been among the most active and influential lobbying organizations in the United States. See William F. Patry, Copyright and the Legislative Process: A Personal Perspective, 14 CARDozo ARTS \& ENT. L.J. 139 (1996); William Patry, The Failure of the American Copyright System: Protecting the Idle Rich, 72 NOTRE DAME L. REV. 907, 922-24 (1997) (noting the strong political power of traditional copyright interests); Sabra Chartrand, Congress Has Extended Its Protection for Goofy, Gershwin, and Some Moguls of the Internet, N.Y. TIMES, Oct. 19, 1998, at C2.

156. See generally MiCHAEL P. RYAN, KNOWLEDGE DiPlOMACY: GlobaL COMPETITION AND THE POLITICS OF INTELLECTUAL PROPERTY ch. 4 (1998).

157. See Bernard Dagenais, AOL Learns Lobby Game Is Necessary Expense, WASH. TIMES, May 24, 1999, at D3; Rick Hepp, Silicon Prairie, CHI. TRIB., Aug. 17, 1999, at N1 (reporting that "the high technology industry is quickly overcoming its aversion to the [political] process in an attempt to influence upcoming legislation and the 2000 elections"); Carla Marinucci \& Marc Sandalow, Silicon Valley Emerges As a Force In Politics: Divided Party Loyalties Put in 2000 Spotlight, S.F. CHRON., May 10, 1999, at A1; Charles Piller, Technet to Campaign for Issues of the 'New Economy'; Politics: Roberta Katz Now Heads the Wealthy Lobbying Group that Is Likely to Be a Major Player in the 2000 Election, L.A. TIMES, June 14, 1999, at C1; Sam Howe Verhovek, 
become deeply involved in lobbying and financing political campaigns.

Intellectual property interests can exert political pressure to prevent state infringement of intellectual property rights at both the state and federal levels. At the state level, they can directly lobby state officials to proscribe infringement of intellectual property rights by state entities and employees. Intellectual property owners can also lobby legislatures to waive sovereign immunity to suits in federal court or to make it easier for intellectual property owners to obtain remedies in state courts. As an inducement, economically powerful companies can threaten to invest only in states that provide sufficient protection for intellectual property rights. If infringement occurs predominantly in a particular sector of state government, such as state universities, then intellectual property interests can focus their efforts on the elected officials and governing boards that oversee and fund those state entities.

At the federal level, intellectual property owners can pursue a range of strategies to combat the risk of state infringement. The intellectual property remedy clarification acts of the early 1990 s were a response to court decisions opening up a state immunity gap in the federal intellectual property system, ${ }^{159}$ and the legislative wheels have already begun to turn since the Florida Prepaid decisions reopened that gap. ${ }^{160}$ Even after the Florida Prepaid decisions, Congress has a range of options for constraining infringement of federal intellectual property rights by states, including clarifying congressional intent to allow Ex parte Young actions to prevent violations of federal law, conditional federal funding, conditional intellectual

Candidates Falling into the Open Arms of High Technology, N.Y. TIMES, May 11, 1999, at A1.

158. Among the leading high-technology intellectual property lobbying organizations are the Business Software Alliance (BSA), the International Intellectual Property Alliance (IIPA), the Pharmaceutical Research Manufacturers of America (PhRMA), and, most recently, Technology Network (TechNet).

159. See Atascadero State Hosp. v. Scanlon, 473 U.S. 234 (1985); Chew v. California, 893 F.2d 331 (Fed. Cir. 1990); Lane v. First Nat'1 Bank of Boston, 871 F.2d 166 (1st Cir. 1989); BV Eng'g v. UCLA, 858 F.2d 1394 (9th Cir. 1988); Richard Anderson Photography v. Brown, 852 F.2d 114 (4th Cir. 1988).

160. See Legislation: Draft Bill Would Restore Right to Sue States for Infringement, 58 PAT. TRADEMARK \& COPYRIGHT J. (BNA) 806 (1999) (summarizing bill proposed by Sen. Patrick Leahy). 
property rights, concurrent jurisdiction extending jurisdiction under 28 U.S.C. $\S 1498$ to include actions against states, federal enforcement, remedial legislation under paragraph 5 of the Fourteenth Amendment, and constitutional amendment.

Ex parte Young Actions. The Supreme Court's decision in Seminole Tribe ${ }^{161}$ added a new wrinkle to the availability of relief in federal court under the doctrine of Ex parte Young. Where a federal statute contains comprehensive enforcement mechanisms inconsistent with an injunctive remedy in federal court, then injunctive relief under the doctrine of Ex parte Young is not available. ${ }^{162}$ Therefore, Congress can enhance the viability of lawsuits brought by intellectual property owners to enjoin infringement of the rights by states by clarifying its intention to allow such remedial relief.

Conditional Funding. Congress has often used its spending power to prod states to implement federal policies. For example, Congress withholds federal highway and other funding from states and state agencies failing to conform to federal pollution standards. ${ }^{163}$ The Supreme Court has upheld the use of conditions in federal funding, even where the federal government arguably impinges upon rights that the U.S. Constitution vests with the states. ${ }^{164}$ Conditional federal funding could be particularly useful to combat infringement of federal intellectual property rights by state universities and research hospitals. The federal government-through the National Institutes of Health, the National Science Foundation, the National Endowment for the Arts, the Department of Energy, the Department of Defense, and other agencies-provides a substantial proportion of research funding to state universities. Therefore, the

161. 517 U.S. 44 (1996).

162. Id. at 73-76. See Meltzer, supra note 31, at 36-48.

163. See, e.g., 42 U.S.C. \& 7506(c)(2) (1999). See also Environmental Defense Fund v. Environmental Protection Agency, 167 F.3d 641 (D.C. Cir. 1999) (holding that federal regulation permitting approval of transportation project that appeared in previous conforming plan but did not appear in currently conforming plan violated Clean Air Act).

164. See South Dakota v. Dole, 483 U.S. 203 (1987) (upholding a federal statute withholding a portion of federal construction funds from states with drinking ages below twenty-one). See generally Meltzer, supra note 31, at 5153 ("There is ... no single unconstitutional conditions doctrine: sometimes conditions on the enjoyment of constitutional rights are tolerated and sometimes not, and no simple formula tells us which is which."). 
federal government could require that state entities respect federal intellectual property rights in order to receive these funds. The federal government could also seek to obtain legislative waivers by the states as a condition for their universities being eligible to receive federal funding.

Conditional Intellectual Property Rights. In the Supreme Court's College Savings Bank decision, Justice Scalia commented that Congress may compel a waiver of sovereign immunity where a state receives a "gift or gratuity" or "federal beneficence" that Congress may rightfully withhold. ${ }^{165}$ Using this option, Senator Leahy has proposed legislation that would require states to waive sovereign immunity from suits that arise under federal intellectual property laws as a condition for obtaining their own federal intellectual property rights. ${ }^{166}$ In his statement introducing the bill, Senator Leahy noted that all fifty states own or have obtained patents and that some states hold several hundred patents. ${ }^{167}$ Congress may not, however, compel state waiver through inducements that are "so coercive as to pass the point at which 'pressure turns into compulsion"”168 or exclude the state from otherwise lawful activity. ${ }^{169}$ It is unclear whether this sort of waiver would be so disproportionate as to constitute improper coercion. ${ }^{170}$

Concurrent Jurisdiction. Under 28 U.S.C. $\S 1338($ a), federal courts have exclusive jurisdiction over patent and copyright infringement actions. Congress could amend this provision to

165. College Sav. Bank v. Florida Prepaid Postsecondary Educ. Expense Bd., 119 S. Ct. 2219, 2231 (1999).

166. See Intellectual Property Protection Restoration Act of 1999, S. 1835, 106th Cong. (1999), reprinted in 58 PAT. TRADEMARK \& COPYRIGHT J. (BNA) 819.

167. See 150 Cong. Rec. S13,557 (daily ed. Oct. 29, 1999) (remarks of Sen. Leahy).

168. Dole, 483 U.S. at 211 (quoting Steward Mach. Co. v. Davis, 301 U.S. 548,590 (1937)).

169. See College Savings Bank, 119 S. Ct. at 2231.

170. Cf. Florida Prepaid Postsecondary Educ. Expense Bd. v. College Sav. Bank, 119 S. Ct. 2199, 2210 (chiding Congress for not limiting "the coverage of the [Patent Remedy] Act to cases involving arguable constitutional violations, such as where a State refuses any state-court remedy for patent owners whose patents it [violates]," or to "types of infringement, such as nonnegligent infringement or infringement authorized pursuant to state policy"). 
authorize state courts to hear infringement actions against states and tailoring available remedies appropriately. States, however, could thwart this means of circumventing the Florida Prepaid decisions. Under the Supreme Court's decision in Alden v. Maine, ${ }^{171}$ states could preclude such suits by not waiving immunity to be sued in their own courts for violations of federal intellectual property law. Creating such concurrent jurisdiction would, at a minimum, force some states to invoke sovereign immunity expressly. Those states with open-ended waiver regimes ${ }^{172}$ would have to exempt such actions affirmatively, which could be politically unpopular.

This proposal could undermine the uniformity of the federal intellectual property system by creating a parallel system of adjudication of intellectual property claims arising under federal law. ${ }^{173}$ As noted in Part I of this Article, however, states were rarely haled into federal court when sovereign immunity did not stand in the way and there are important social and political constraints upon state infringement of federal intellectual property rights. In addition, even though the Eleventh Amendment stands in the way of suits being filed in federal court against states for infringement of intellectual property rights without their consent, Congress could require that appeals of state court adjudications of federal intellectual property rights be heard exclusively in federal courts of appeal-with patent appeals directed to the Federal Circuit and appeals of other intellectual property cases channeled to the appropriate regional court of appeals. This option would limit the extent to which state court systems would stray from federal court interpretation of intellectual property law.

Federal/State Compromise. Part of the reason that states take umbrage at the intellectual property remedy clarification acts is that they expose states to greater potential liability than the federal

171. 527 U.S. 706 (1999).

172. See supra note 82 and accompanying text.

173. See H.R. Rep. No. 101-282, 101st Cong., 1st Sess. 9 (1989) (commenting that allowing state court adjudication of federal copyright claims would frustrate the "essential premise" of the Copyright Act of 1976 "to create a uniform Federal system for the creation and enforcement of copyrights"). 
government for infringement of federal intellectual property rights. ${ }^{174}$ The federal government is not liable for injunctive relief, treble damages for willful patent infringement, or more than the minimal statutory damages, ${ }^{175}$ whereas the remedy clarification acts sought to treat states no differently than private actors, exposing them to the full range and extent of remedies available in lawsuits against private infringers. The federal government might able to achieve an adequate and more politically viable result by expanding 28 U.S.C. $\S 1498$ to authorize suits against states on the same terms as those applicable to the federal government. This approach respects the dignity of states while providing intellectual property owners with an established means of enforcing their rights in a federal forum. Furthermore, given the distinctive character of public institutions, ${ }^{176}$ there is a strong normative basis for not subjecting governmental entities to punitive and intent-based remedies. Governments do not operate as profit-oriented enterprises and are subject to freedom of information requirements and open meeting laws that reduce the risk of undetected infringement. As an inducement to states participating in this regime (and formally waiving sovereign immunity), Congress could couple this change with either the conditional funding ${ }^{177}$ or conditional intellectual property rights ${ }^{178}$ proposals. Such a linkage would be less likely to struck down as so disproportionate as to constitute improper coercion.

Federal Enforcement. Because the Eleventh Amendment does not immunize states from lawsuits by the United States in federal court, Congress could develop a new mechanism for enforcing federal intellectual property rights against states. For example, Congress could enact a regime authorizing federal authorities to enforce federal intellectual property rights against states and state entities.

174. See Eugene Volokh, Sovereign Immunity, 73 UNIV. SO. CAL. L. REV. (forthcoming 2000).

175. See 28 U.S.C. $\S 1498$ (limiting patent and copyright recovery to "reasonable and entire compensation" including minimum statutory damages in the case of copyright infringement); 28 U.S.C. $§ 2412(\mathrm{~d})(1)(\mathrm{A})$ (addressing costs and fees).

176. See supra Part I.B.

177. See supra notes $163-64$ and accompanying text.

178. See supra notes $165-70$ and accompanying text. 
Under this regime, intellectual property owners could petition the U.S. Department of Justice to initiate law suits seeking relief-injunctions and damages-against states. A separate provision could enable the intellectual property owner to recover any monetary awards paid to the federal government. This procedure would obviously be cumbersome. It is unlikely, however, that it would be invoked with great frequency. In addition, it could be limited by allowing an appropriate federal official, such as the Director of the Patent and Trademark Office, to decide whether to pursue a particular petition.

An alternative means of achieving this result could be through the use of a qui tam regime. The qui tam model enables private individuals to vindicate the rights of the government. ${ }^{179}$ It might be possible to reconceptualize private intellectual property rights to allow for government vindication of those rights. One further step would be to then allow private individuals to bring suits to vindicate such rights on behalf of the federal government. It should be noted, however, that the Supreme Court is currently considering whether states are persons under the False Claims Act and if so, whether states have immunity from qui tam suits brought under that Act. ${ }^{180}$

Remedial Legislation. The Supreme Court's Florida Prepaid decision substantially raised the bar for congressional abrogation of state sovereign immunity pursuant to paragraph 5 of the Fourteenth Amendment, but it did not preclude this option entirely. Intellectual property owners will need to adduce much more substantial evidence of state infringement of federal intellectual property rights, both in terms of the number of violations and the willfulness of the violations, in order to justify congressional abrogation of state sovereign immunity, ${ }^{181}$ as well as evidence that state remedies are

179. See, e.g., 31 U.S.C. $\S 3730$ (b) (authorizing private individual to bring a civil action on the government's behalf to remedy false claims against the federal government).

180. See Vermont Agency of Natural Resources v. United States ex rel. Jonathan Stevens, 162 F.3d 195 (2d Cir. 1998), cert. granted, 119 S. Ct. 2391 (1999).

181. See Florida Prepaid, 119 S. Ct. at 2210 (citing City of Boerne v. Flores, 521 U.S. 507, 526 (1997)) (suggesting that the legislative record would have to establish "a history of "widespread and persisting deprivation of constitutional rights' of the sort Congress had faced in enacting proper prophylactic $\S 5$ leg- 
inadequate. ${ }^{182}$ The Supreme Court did not establish a clear threshold for when this burden is met, but it did suggest that evidence of intentional violations of federal intellectual property rights would be important in making the determination. ${ }^{183}$ For the reasons discussed above, ${ }^{184}$ state infringement might never rise to the level necessary to justify remedial legislation. And even if a pattern of patent infringement could be demonstrated, intellectual property owners would also have to demonstrate that state remedies were inadequate. Thus, in order for Congress to abrogate state sovereign immunity, intellectual property owners would have to establish, through monitoring and unsuccessful efforts to obtain remedies through state legal and administrative processes, both a substantial pattern of state infringement and the lack of adequate state remedies. And even then, Congress could only abrogate sovereign immunity to the extent necessary to remedy the constitutional violation. ${ }^{185}$

Constitutional Amendment. The clearest way to abrogate sovereign immunity for state infringement of federal intellectual property rights would be through a constitutional amendment. This approach, however, would face insuperable obstacles. In the entire history of the United States, the complex process of amending the Constitution has only been successfully used to override Supreme Court decisions on four or five occasions. ${ }^{186}$ It is unlikely that sufficient support could be garnered to place this issue on the level of prior constitutional amendments. Even if two-thirds of the Congress were to support such a constitutional amendment, it is doubtful that many states would rush to ratify it. ${ }^{187}$

\section{islation").}

182. See id. at 2207-08.

183. See id. at 2209 (noting that "a state actor's negligent act that causes unintended injury to a person's property does not 'deprive' that person of property within the meaning of the Due Process Clause").

184. See supra Part I.B.

185. See Florida Prepaid, 119 S. Ct. at 2210 (suggesting that Congress could not abrogate sovereign immunity with regard to negligent infringement, nor of states with adequate remedies or low incidence of infringement).

186. See LAURENCE H. TRIBE, AMERICAN CONSTITUTIONAL LAW 64-65 n.10 (2d ed. 1988).

187. See U.S. CONST. art. V (requiring ratification of constitutional amendments by three-fourths of the states). 
The viability of these various approaches depends upon the extent of the problem, the salience of the issue, and the political strength of the states in resisting such efforts. Intellectual property owners can exert direct pressure upon legislators through lobbying and campaign financing. They can also bring attention to the problems of state infringement by monitoring the behavior of state entities, bringing high-profile lawsuits, and waging public relations campaigns against states that do not respect federal intellectual property rights. The efficacy of these efforts, however, will depend significantly upon the extent of the problem. If states and state entities do not engage in widespread or otherwise significant acts of infringement, then the opportunity to catalyze the political process will be modest. As the seriousness of the problem escalates, however, so will the viability of more substantial political responses. In this way, political constraints tighten as the magnitude of the problem rises.

In the most likely scenario, states will continue to respect federal intellectual property rights and infringements of these rights by state actors will be unintentional, episodic, and relatively rare. Where infringement occurs, the Florida Prepaid decisions present a challenge and opportunity for intellectual property lawyers to test the efficacy and limits of Ex parte Young, $\S 1983$, and takings actions in the federal courts. In addition, they will likely be able to pursue state inverse condemnation actions and possibly tort, state intellectual property, or contract claims, many of which are largely untested in most of the states. In those areas in which states or state entities cross the infringement line more systematically, the Florida Prepaid decisions present challenges to business strategists to develop safeguards against state infringement-whether through trade secrecy, technical solutions (e.g., encryption, anti-circumvention technologies), and new contracting approaches. Should states cavalierly infringe federal intellectual property rights, then intellectual property owners will likely organize political campaigns at the state and federal levels in order to combat abuses through a range of approaches including direct involvement in state politics, waiver, and the use of contingencies in federal funding of programs and research. In addition, they will seek (and already are seeking) creative federal legislative means for filling the gap created by the Florida Prepaid decisions. And if state infringement of federal intellectual property rights surpass the 
rather vague threshold suggested in Florida Prepaid, ${ }^{188}$ Congress has authority under the Fourteenth Amendment to abrogate state sovereign immunity directly. ${ }^{189}$

In view of the multiplicity of institutional constraints upon state infringement of federal intellectual property rights, the Florida Prepaid decisions are likely to have more of a symbolic than substantive impact on state policies respecting intellectual property rights. Yet in a few areas-such as the use of patented research methods in basic research conducted at state universities-state institutions may toe and possibly cross the line. Here, the narrow experimental use exception of the federal patent system may undermine innovation by hindering basic research of the type that is the hallmark of university research. ${ }^{190}$ Although the increasingly commercial character of state university research may alter this assessment, the effect of greater leeway for universities to engage in basic research without concern for patent licensing arguably will have an ambiguous or positive impact on progress in biomedical and other areas of scientific research.

This is not to say, however, that the Supreme Court's rulings in the Florida Prepaid cases do not impose real costs upon some intellectual property owners, complicate the enforcement of intellectual property rights, and as a result undermine the promotion of science and the useful arts. The uncertainty and cost of enforcing intellectual property rights against states will discourage those with smaller stakes from pursuing relief and will raise the costs for those seeking relief. In addition, the constraints on enforcement will raise the costs of contracting and monitoring transactions with state entities. Overall, however, the net effects of the Florida Prepaid decisions on the incentives for creative activities are unlikely to be large and several

188. See Florida Prepaid, 119 S. Ct. at 2206-11.

189. A constitutional amendment abrogating state sovereign immunity with respect to federal intellectual property infringement actions (or authorizing Congress to abrogate such immunity) remains a last resort, but with daunting odds. The U.S. Constitution is rarely amended, and this issue is neither pressing nor compelling to the states. It is difficult to imagine two-thirds of the states consenting to reduce their sovereign immunity, particularly over an issue such as this one.

190. See Rebecca S. Eisenberg, Patents and the Progress of Science: Exclusive Rights and Experimental Use, 56 U. CHI. L. REV. 1017 (1989); Arti Kaur Rai, Regulating Scientific Research: Intellectual Property Rights and the Norms of Science, 94 Nw. U. L. REV. 77 (1999). 
redundant systems for protecting intellectual property and selfcorrecting features of the intellectual property system will limit the exposure of intellectual property owners to the gap opened up by the Florida Prepaid decisions.

\section{INTERNATIONAL IMPLICATIONS OF THE FLORIDA PREPAID DECISIONS}

Although various institutional constraints will likely prevent or at least substantially restrain states from infringing federal intellectual property rights in significant or pervasive ways, the Supreme Court's Florida Prepaid decisions pose potential problems for the United States in several international arenas. The rise of digital technologies, advancements in transportation technologies, and reductions in trade barriers have dramatically increased international trade flow. ${ }^{191}$ Industries based upon new technologies and whose value is derived significantly from intellectual property have spurred American exports. American entertainment industries, software and computer manufacturing companies, and pharmaceutical companies derive substantial and growing proportions of their revenue streams from their export operations and comprise a growing share of U.S. exports. These products, however, are vulnerable to low cost duplication in countries lacking intellectual property protections or effective enforcement mechanisms. The concerns of intellectual property owners with regard to international piracy has, over the past two decades, led the United States to pursue an increasingly more assertive role in promoting the adoption of intellectual property protections throughout the world, the harmonization of international protection for intellectual property, and improvement of global institutions governing intellectual property rights. ${ }^{192}$ The Agreement on TradeRelated Aspects of Intellectual Property Rights (TRIPs), the North American Free Trade Agreement (NAFTA), and the World Intellectual Property Organization (WIPO) Copyright Treaty, for which the United States aggressively lobbied, established minimum criteria for

191. See Jerome H. Reichman, The TRIPs Component of the GATT's Uruguay Round: Competitive Prospects for Intellectual Property Owners in an Integrated World Market, 4 FORDHAM INTELL. PROP. MEDIA \& ENT. L.J. 171 (1993).

192. See RYAN, supra note 156 , at chs. 4 \& 7 . 
intellectual property regimes. Furthermore, the United States has forcefully objected to perceived weaknesses in the intellectual property laws of other nations. By opening a constitutional loophole of debatable scope in the U.S. intellectual property regime, the Supreme Court's recent decisions raise serious questions regarding U.S. compliance with international accords and undermine the credibility of the United States in international intellectual property diplomacy.

\section{A. Compliance with International Accords}

Over the past decade, the United States has actively built consensus for the establishment of new multilateral agreements for the protection and enforcement of intellectual property rights. TRIPs and NAFTA are particularly important in that they have relatively strong and effective dispute resolution mechanisms. Unlike many prior international agreements regarding intellectual property, these newer agreements establish relatively clear minimum standards for the protection and enforcement of intellectual property rights. The Florida Prepaid decisions, by striking down congressional abrogation of state sovereign immunity from direct infringement actions in federal courts, expose the United States to claims that it has failed to comply with these international accords.

\section{Trade-related aspects of intellectual property rights (TRIPs) agreement $^{193}$}

United States trade diplomats used trade negotiations at the Uruguay Round of the General Agreement on Tariffs and Trade (GATT), begun in 1986, to bring intellectual property protections into trade negotiations. By linking tariff reductions on apparel and agricultural goods with universal minimum standards of intellectual property protection, developed nations were able to persuade developing nations to accede to the TRIPs agreement. ${ }^{194}$

193. Agreement on Trade-Related Aspects of Intellectual Property Rights, Apr. 15, 1994, Marrakesh Agreement Establishing the World Trade Organization [hereinafter WTO Agreement], Annex 1C, LEGAL INSTRUMENTSRESULTS OF THE URUGUAY ROUND vol. 31, 33 I.L.M. 81 (1994) [hereinafter TRIPs Agreement].

194. See Michael E. Doane, TRIPS and International Intellectual Property Protection in an Age of Advancing Technology, 9 AM. U. J. INT'L L. \& POL'Y 465 (1994). Articles 65 and 66 of the TRIPs agreement provide for a transi- 
Part II of the TRIPs agreement establishes minimum standards concerning the availability, scope, and use of intellectual property rights. It covers copyright and related rights, trademarks, industrial designs, patents, and integrated circuit designs. Under each section, the agreement limits the exceptions which member nations may enact. With regard to copyright and related rights, "Members shall confine limitations or exceptions to the exclusive rights to certain special cases which do not conflict with a normal exploitation of the work and do not necessarily prejudice the legitimate interests of the right holder." 195

Similar provisions apply to trademarks ${ }^{196}$ and patents. ${ }^{197}$ Article 31 provides for a limited exception for government use without authorization of the right holder: "[S]uch use may only be permitted if, prior to such use, the proposed user has made efforts to obtain authorization from the right holder on reasonable commercial terms and conditions and that such efforts have not been successful within a reasonable time." 198 Article 31 allows members to dispense with such efforts in circumstances of national emergency, exigency, or cases of public noncommercial use. In all cases, however, the member state must notify the right holder as soon as "reasonably practicable." 199 Article 31 further provides that "the right holder shall be paid adequate remuneration in the circumstances of each case, taking into account the economic value of the authorization."200 The legal validity of such authorization must be subject to judicial review.

Part III of the TRIPs agreement provides for the enforcement of intellectual property rights. Article 41 states that

1. Members shall ensure that enforcement procedures as specified in this Part are available under their law so as to permit effective action against any act of infringement of

tional period for developing nations. Article 67 requires developed countries to provide technical assistance to developing countries in the drafting of intellectual property laws and regulations.

195. TRIPs Agreement, supra note 193, art. 13.

196. See id. art. 17 (trademarks), art. 24 (applying to geographical indications).

197. See id. art. 30.

198. Id. art. 31.

199. Id.

200. Id. 
intellectual property rights covered by this Agreement, including expeditious remedies to prevent infringements and remedies which constitute a deterrent to further infringement. These procedures shall be applied in such a manner as to avoid creation of barriers to legitimate trade and to provide for safeguards against their abuse.

2. Procedures concerning the enforcement of intellectual property rights shall be fair and equitable. They shall not be unnecessarily complicated or costly, or entail unreasonable time-limits or unwarranted delays . . . ${ }^{201}$

Article 41 further requires that members provide an opportunity for judicial review. TRIPs also establishes minimum criteria for remedies. Article 44 requires that judicial officers have authority to order injunctive relief (including desist orders). ${ }^{202}$ Article 45 requires that

1. The judicial authorities shall have the authority to order the infringer to pay the right holder damages adequate to compensate for the injury the right holder has suffered because of an infringement of that person's intellectual property right by an infringer who knowingly, or with reasonable grounds to know, engaged in infringing activity.

2. The judicial authorities shall also have the authority to order the infringer to pay the right holder expenses, which may include appropriate attorney's fees ... ${ }^{203}$

Article 46 requires that judicial authorities have the power to order that infringing goods, materials, and implements used predominately in the creation of infringing goods be seized and appropriately removed from commerce. ${ }^{204}$ Article 61 requires members to apply criminal procedures and penalties in the cases of wilful trademark counterfeiting or copyright piracy on a commercial scale. ${ }^{205}$

The World Trade Organization, which succeeds the GATT, oversees implementation of the TRIPs agreement. Under the WTO Dispute Settlement Understanding, members of TRIPs may initiate proceedings against other members for failure to implement TRIPs

201. Id. art. 41.

202. See id. art. 44.

203. Id. art. 45.

204. See id. art. 46.

205. See id. art. 61. 
requirements. ${ }^{206}$ It is unclear whether a member may obtain a remedy against another member for a single breach of the obligation to provide effective enforcement or only for systemic failures. ${ }^{207}$ In any case, immunity of states and state entities from infringement of federal intellectual property rights would appear to qualify as a basis for a remedy.

The United States could defend its system on the ground that state officers may, under certain circumstances, be liable under the Ex parte Young doctrine for prospective injunctive relief and under $\S$ 1983 for damages. In addition, alternative remedies in state courts may be available. It is questionable whether this hodge podge of potential remedies would satisfy TRIPs's minimum criteria. Even before the Florida Prepaid decisions, it is questionable whether the United States fully adhered to Article 31 with regard to notification of patent owners that their inventions were being used by government entities. ${ }^{208}$ Following the Florida Prepaid decisions, enforcement of intellectual property rights against states would fall below this Article 31 criteria. In addition, it is questionable whether states would provide adequate or timely remedies for infringements.

TRIPs does not contain any exceptions based upon the distinctively American approach to state sovereignty and federalism. The limitations on enforcement would appear to conflict with normal

206. See Frederick M. Abbott, WTO Dispute Settlement and the Agreement on Trade-Related Aspects of Intellectual Property Rights, in INTERNATIONAL TRADE LAW AND THE GATT-WTO DisPUTE SETTLEMENT SYSTEM 415 (E.U. Petersmann ed., 1997).

207. Id.

208. The European Communities have noted that:

Under U.S. law (28 US Code Section 1498) a patent owner may not enjoin or recover damages on the basis of his patents for infringements due to the manufacture or use of goods by or for the US Government Authorities. This practice is particularly frequent in the activities of the [Department of Defense] but is also extremely widespread in practically all government departments. For obvious reasons this practice is particularly detrimental to foreign right-holders because they will generally not be able to detect governmental use and are thus very likely to miss the opportunity to initiate the administrative claims procedure.

European Commission, Report on United States Barriers to Trade and Investment $\S 6.1$ (1997). 
exploitation of intellectual property works and would prejudice the legitimate interests of the right holder.

Member states of international accords do not typically proceed against other member states on the basis of each and every perceived inconsistency or violation of international agreements. Nations resolve to examine a broad range of foreign trade and other diplomatic considerations in deciding whether and how to pursue the enforcement of international law provisions. To put this in perspective, after an exhaustive review, the United States Trade Representative (USTR) has concluded that no foreign nation satisfies all of the minimum criteria set forth in the TRIPs agreement. ${ }^{209}$ Yet the more vulnerable the United States is to claims of noncompliance, the greater its exposure to enforcement actions and the more difficulty it will face in seeking trade and other concessions from other nations.

\section{The North American Free Trade Agreement}

As part of its multifaceted strategy to strengthen intellectual property rights throughout the world, the United States pushed for the inclusion of intellectual property protections in its regional trade agreement with Canada and Mexico. NAFTA provides that "Each party shall provide in its territory to the nationals of another Party adequate and effective protection and enforcement of intellectual property rights, while ensuring that measures to enforce intellectual property rights do not themselves become barriers to legitimate trade."210 Article 1714 states that "each Party shall ensure that enforcement procedures . . . are available under its domestic law so as to permit effective action to be taken against any act of infringement of intellectual property rights, ... including expeditious remedies to prevent infringements and remedies to deter further infringements." 211 Each member state is to "ensure that its procedures for the enforcement of intellectual property rights are fair and equitable, are not unnecessarily complicated or costly, and do not entail

209. See USTR Fact Sheets on Super 301 Trade Liberalization Priorities and Special 301 on Intellectual Property, 6 INT'L TRADE RPTR. (BNA) 715, 719 (1989).

210. North American Free Trade Agreement, Dec. 8-17, 1992, U.S.-Can.Mex., art. 1701, 32 I.L.M. 289, at $\S 1$ [hereinafter NAFTA].

211. Id. art. 174. 
unreasonable time-limits or unwarranted delays." ${ }^{\text {,12 }}$ NAFTA allows parties to provide "limited exceptions to the exclusive rights conferred by a patent, provided that such exceptions do not unreasonably conflict with a normal exploitation of the patent and do not unreasonably prejudice the legitimate interests of the patent owner, taking into account the legitimate interests of other persons."213

The NAFTA language largely tracks the TRIPs provisions. A signatory's authority to make exceptions are similarly limited. NAFTA focuses more narrowly upon the protection of intellectual property rights of foreign nationals and not the integrity of the overall intellectual property regime. Canada and Mexico would be able to challenge the United States regime to the extent that states and state entities are beyond the effective and timely reach of foreign intellectual property owners.

\section{World Intellectual Property Organization Copyright Treaty}

The United States also played a substantial role in the development of the WIPO Copyright Treaty which, like TRIPs and NAFTA, required signatory nations to establish minimum criteria for the protection of intellectual property works. In addition to reaffirming parties' adherence to the Berne Convention, the WIPO Copyright Treaty obligates signatories "to provide adequate legal protection against the circumvention of effective technological measures that are used by authors in connection with the exercise of their rights under this Treaty or the Berne Convention . . .."214 Article 12 obligates contracting parties to "provide adequate and effective legal remedies against any person knowingly performing" acts which they

\section{2. $I d$.}

213. Id. art. $1709, \S 6$. NAFTA has similar limitations on exceptions for copyright, see id. art. $1705, \S 5$ ("Each Party shall confine limitations or exceptions to the rights provided for in this Article to certain special cases that do not conflict with a normal exploitation of the work and do not unreasonably prejudice the legitimate interests of the right holder."); sound recordings, see $i d$. art. 1706, § 3 (same as copyright); and trademarks, see id. art. 1708, § 12 ("A Party may provide limited exceptions to the rights conferred by a trademark, such as fair use of descriptive terms, provided that such exceptions take into account the legitimate interests of the trademark owner and of other persons.").

214. WIPO Copyright Treaty, Dec. 20, 1996, S. TREATY Doc. No. 105-17, at 10 (1997). 
have reason to know will "induce, enable, facilitate or conceal an infringement of any right covered by this treaty or the Berne Convention." 215 The United States amended its copyright law in 1998 to implement this treaty. ${ }^{216}$

The only exception within the WIPO Copyright Treaty is rather narrow:

Contracting Parties may, in their national legislation, provide for limitations of or exceptions to the rights granted to authors of literary and artistic works under this Treaty in certain special cases that do no conflict with a normal exploitation of the work and do not unreasonably prejudice the legitimate interests of the author. ${ }^{217}$

As with TRIPs and NAFTA, the exception here would not justify immunity for states and state entities. The principal defense would have to be that alternative legal and administrative remedies are substantially equivalent to direct infringement actions under the Copyright Act.

\section{B. Intellectual Property Diplomacy}

In response to mounting trade deficits, Congress enacted the Trade Act of $1974,{ }^{218}$ which revised the Trade Expansion Act of 1962 to allow the President to restrict imports from countries that had unreasonably restricted U.S. exports. Section 301 authorizes the President to retaliate against foreign countries for engaging in "unfair" trade practices, even if such practices had not been found to contravene international law. ${ }^{219}$ The United States used this

215. Id. at 11.

216. See Digital Millennium Copyright Act, Pub. L. No. 105-304, 112 Stat. 2860 (codified as amended at 17 U.S.C. $§ 101$ (1999)).

217. WIPO Copyright Treaty, supra note 215 , art. 10(1).

218. Trade Act of 1974, Pub. L. No. 93-618, $\$ \S 301-306,88$ Stat. 1978 (codified at 19 U.S.C. $\$ \S 2411-2416(1994)$ ).

219. Section 301 authorizes domestic industries to petition the U.S. Trade Representative to investigate allegations of unfair trade practices limiting U.S. exports. In addition, the USTR may initiate its own investigations. After investigation and consultation with relevant foreign country representatives, the USTR determines whether United States trade agreement rights have been violated or whether the foreign country has engaged in unfair trade practices. The Trade Act requires that remedies be implemented if trade rights are denied or if unjustifiable trade practices are found. The Trade Act allows the USTR 
unilateral power in bilateral interactions to pressure foreign nations to adopt more liberal trade practices and as part of a concerted effort to achieve multilateral agreements. ${ }^{220}$

By the early 1980s, American businesses relying heavily upon intellectual property rights mobilized their forces to focus U.S. trade policy on piracy of intellectual property abroad. ${ }^{221}$ In 1984, Congress amended the Trade Act to expressly authorize retaliation against nations failing to protect and enforce intellectual property rights. ${ }^{222}$ Congress further strengthened the hand of U.S. trade negotiators through the passage of the Omnibus Trade and Competitiveness Act of $1988 .{ }^{223}$ In a set of provisions that have come to be known as "Special 301,"224 Congress directed the USTR to develop an annual list of "priority" countries that "have the most onerous or egregious acts, policies, or practices that (i) deny adequate and effective intellectual property rights, or (ii) deny fair and equitable market access to United States persons that rely upon intellectual property protection." 225 The USTR must investigate these nations' practices and may take action. If the investigation reveals that the priority list country has denied U.S. rights and has not made progress in remedying these problems within eighteen months of the initiation of the investigation, then the President must pursue responsive action. ${ }^{226}$

discretion to recommend remedies where it finds unreasonable or discriminatory trade practices.

220. See Frederick M. Abbott, Protecting First World Assets in the Third World: Intellectual Property Negotiations in the GATT Multilateral Framework, 22 CAN. J. TRANSNAT'L L. 689 (1989).

221. See RYAN, supra note 156, at 167-72.

222. Trade and Tariff Act of 1984, Pub. L. No. 96-39, 93 Stat. 295 (1979); Pub. L. No. 98-573, §§ 304, 306, 98 Stat. 3002 (1984). The 1984 Act also expanded the scope of the Trade Act to include services.

223. Pub. L. No. $100-48,102$ Stat. 1107 (codified as amended in various sections of 19 U.S.C.).

224. See Judith H. Bello \& Alan F. Holmer, "Special 301": Its Requirements, Implementation, and Significance, 13 FORDHAM INT'L L.J. 259 (198990); Brian Mark Berliner, Making Intellectual Property Pirates Walk the Plank: Using "Special 301" to Protect the United States' Rights, 12 LOY. L.A. INT'L \& COMP. L.J. 725 (1990).

225. 19 U.S.C. $\$ 2242(\mathrm{~b})(1)(\mathrm{A})(1999)$.

226. See id. $\S \S 2411(a), 2414(a)$. 
The USTR has implemented Special 301 law with particular zeal. Its priority list documents in significant detail a tremendous number of impediments to the protection of intellectual property rights of U.S. domestic industries in foreign nations. ${ }^{227}$ Substantially every trading partner comes under scrutiny. ${ }^{228}$ The USTR has opened more than one hundred investigations, many in the past decade focusing on allegations that trading partners deny adequate and effective intellectual property rights.

Two prominent efforts by the USTR to push for stronger intellectual property rights in foreign countries illustrate the ways in which the Florida Prepaid decisions could potentially undermine U.S. credibility in foreign trade and intellectual property diplomacy. The first involves a protracted dispute with the People's Republic of China focusing on piracy of copyrighted works. The second, of more recent vintage, involves a new South Africa law providing the Minister of Health with discretion in expanding the dissemination of pharmaceutical products.

The USTR listed China on its 1989 Special 301 priority list based on complaints by the International Intellectual Property Alliance and others that China tolerated widespread piracy of copyrighted books, films, music, and software. ${ }^{229}$ Numerous factories in southern China were producing millions of compact and laser discs for distribution throughout Asia. ${ }^{230}$ U.S. copyright owners alleged that the government was actively involved in pirating intellectual property through government corruption. ${ }^{231}$ The USTR instituted a formal Section 301 investigation in 1991 and has been actively engaged in efforts to address gaps in China's intellectual property regime throughout the $1990 \mathrm{~s}^{232}$

227. See U.S. Trade Representative, 1999 National Trade Estimate (visited Mar. 26, 2000) <http://www.ustr.gov/reports/nte/1999>.

228. See U.S. Trade Representative, Section 301 Table of Cases (last modified Aug. 9, 1999) <http://www.ustr.gov/reports/301 report/act301.htm>.

229. See INTERNATIONAL INTELlectual PROPERTY AllianCE, TRADE LOSSES DUE TO PIRACY AND OTHER MARKET ACCESS BARRIERS AFFECTING THE U.S. COPYRIGHT INDUSTRIES 57-66 (Apr. 1989).

230. See RYAN, supra note 156 , at 80 .

231. See id. at 81.

232. See id. at 81-84. 
The perception that states and state entities within the United States have immunity from infringement liability for violation of intellectual property rights could provide China and other centrally planned economies with a simple and rhetorically effective response to U.S. efforts to close down pirate factories abroad. These countries could merely mimic U.S. law. As discussed in Part I, federal and state law provide numerous avenues of legal recourse against infringement of federal intellectual property rights by states and state entities. Furthermore, it is unlikely that states will engage in systematic infringement of federal intellectual property rights. These realities, however, do not necessarily carry the day in the rough and tumble world of international trade politics. China or other centrally planned economies could emulate state sovereignty and provide cumbersome and largely ineffective state remedies, all the while claiming they have the same substantive law as the United States. In the end, diplomacy efforts depend on a broad range of factors. Yet erosion of legal and moral high ground does not enhance the effectiveness of U.S. trade negotiators.

A recent trade intellectual property dispute with South Africa further illustrates the way in which state sovereign immunity interacts with trade relations. In an effort to respond to an ADS epidemic affecting a substantial proportion of its population, ${ }^{233}$ South Africa amended its Medicines and Related Substances Control Act in 1997 to authorize the Minister of Health to order compulsory licensing and parallel importation of pharmaceuticals. ${ }^{234}$ The pharmaceutical industry considered the vague and open-ended authority of this law to be a serious threat to the protection of intellectual property rights. ${ }^{235}$ The United States called on the South African government to "bring its IPR [intellectual property rights] regime into full compliance with TRIPS before the January 1,2000 deadline . . . and

233. See Hanging on to the Profits from AIDS; Sufferers in Africa Are Threatened by Sanctions Against Cheap Drugs, GuARDIAN (London), Aug. 5, 1999, at 18; Minister Predicts Six Million South Africans with HIV (visited June 5, 2000) <http://www.cnn.com/world/africa/9908/25/bc-AIDSSAFRICA.reut>.

234. See Medicines and Related Substances Control Amendment Act 90 of 1997, 3 JSRSA $\S 1$ (1998).

235. See Claire Bisseker, Cheaper Medicine at a Price * Health Policy, FIN. MAIL (S. AFR.), Oct. 17, 1997, at 36. 
clarify that the powers granted in the Medicines Act are consistent with its international obligations and will not be used to weaken or abrogate pharmaceutical patent protection."236 Yet under a regime of state sovereign immunity, pharmaceutical companies could not bring direct patent infringement actions against state hospitals that pirated patented drugs. As explained in Part I, such a policy or action is unlikely to be adopted, and if it were to be pursued, various avenues of legal recourse remain available to patent holders to enjoin such action and seek recompense. Nonetheless, the fact remains that it would not be through a direct infringement action and would encounter substantial procedural and substantive obstacles to expeditious, full, and fair relief. As a result, South Africa and other nations that adopt more lax intellectual property policies may be able to counter U.S. diplomacy to tighten their intellectual property regimes.

The argument can be made that United States intellectual property trade diplomacy often reflects a narrow view of intellectual property issues shaped principally by the interests of U.S. intellectual property owners. ${ }^{237}$ While it may well be the case that special interests have had disproportionate influence in setting the U.S. diplomatic agenda, the solution to that problem lies in improving campaign finance, ethics in government, limits on post-government lobbying, and related laws designed to ensure balanced and objective representation and discourage capture of government decisionmaking processes. It should not be through undermining the effectiveness of foreign diplomacy. The issue raised by state sovereign immunity from liability for infringement of intellectual property rights relates principally to whether the United States should have a unified and effective voice in its foreign relations activities. The

236. See Helaine Klasky, USTR Announces Results of Special 301 Annual Review, (visited Apr. 30, 1999) <http://www.ustr.gov/releases/1999/04/9941.html >; see also United States Department of State, U.S. Government Efforts to Negotiate the Repeal, Termination or Withdrawal of Article 15(c) of the South African Medicines and Related Substances Act of 1997 (visited Jan. 21, 2000)<http://www.cptech.org/ip/health/sa/stdept-feb51999.html>.

237. See Pamela Samuelson, The Digital Agenda of the World Intellectual Property Organization: Principal Paper: The U.S. Digital Agenda at WIPO, 37 VA. J. INT'L L. 369 (1997); RYAN, supra note 156; October 6, 1999 letter to Charlene Barshefsky regarding review of U.S. trade policy as it relates to access to essential drugs (visited Apr. 1, 2000) $<$ http://www.cptech.org/ip/health/country/cb-oct6-99.html>. 
Florida Prepaid decisions undermine such authority by potentially putting beyond the reach of the federal government the ability to implement a fair and effective system of intellectual property protection and enforcement. This problem will become more acute as intellectual property becomes an increasingly international issue. As the China and South Africa examples illustrate, state sovereign immunity represents a potentially enormous loophole in the development of a truly global system of protection for intellectual property. Thus, the Supreme Court's opening of a state immunity gap within the federal intellectual property enforcement scheme may have significant adverse long-term effects on the climate for innovation in the United States by undermining the federal government's credibility in intellectual property diplomacy efforts.

\section{International Treaty Obligations and Foreign Relations as Bases for Congressional Abrogation of State Sovereign Immunity for Infringement of Federal Intellectual Property Rights}

These threats to international diplomacy provide an alternative basis within established constitutional principles on which to justify congressional abrogation of state sovereign immunity for infringement of federal intellectual property rights. The Necessary and Proper Clause of the U.S. Constitution empowers Congress to enact legislation implementing foreign treaties ratified by the United States. $^{238}$ Because state sovereignty has never been understood to extend to international affairs, ${ }^{239}$ the Eleventh Amendment would not

238. See U.S. CoNST. art. I, $\S 8$, cl. 18; see also Missouri v. Holland, 252 U.S. 416, 432 (1920); Neely v. Henkel, 180 U.S. 109, 121-22 (1901); Martin S. Flaherty, Are We to be a Nation?: Federal Power vs. "States' Rights" in Foreign Affairs, 70 U. COLO. L. REV. 1278 (1999); Thomas Healy, Note, Is Missouri v. Holland Still Good Law? Federalism and the Treaty Power, 98 COLUM. L. REV. 1726 (1998); cf. Perez v. Brownell, 356 U.S. 44, 57 (1958) (noting that although the Constitution does not expressly grant Congress authority to regulate foreign affairs, "there can be no doubt of the existence of this power in the law-making organ of the Nation"); United States v. Curtiss-Wright Export Corp., 299 U.S. 304, 318 (1936) (stating that the powers of the United States to conduct foreign affairs do not derive from the Constitution, but are inherent from the sovereignty of the nation).

239. See Ioannou v. New York, 371 U.S. 30, 31 (1962) ("The Constitution by Art. I, $\S 10$, imposes severe limitations on the several States' power to affect the foreign relations of the United States."). 
appear to limit this aspect of Congress's Article I powers. ${ }^{240}$ Therefore, Congress could plausibly justify a re-enactment of the intellectual property remedy clarification acts as implementing U.S. treaty obligations under TRIPs, NAFTA, and the WIPO Copyright Treaty. ${ }^{241}$

Although NAFTA and TRIPs were approved as CongressionalExecutive Agreements $^{242}$ (requiring simple majorities of both

240. It could be argued that the Supreme Court's decision in Florida Prepaid holds that Congress lacks authority under Article I to abrogate state sovereign immunity. The Court states that

In Seminole Tribe, of course, this Court overruled the plurality in Pennsylvania v. Union Gas Co., 491 U.S. 109 (1989), our only prior case finding congressional authority to abrogate state sovereign immunity to an Article I power (the Commerce Clause). 517 U.S., at 7273. Seminole Tribe makes clear that Congress may not abrogate state sovereign immunity pursuant to its Article I powers; hence the Patent Remedy Act cannot be sustained under either the Commerce Clause or the Patent Clause. Id.

119 S. Ct. at 2205 . This language is merely restating Seminole Tribe, which did not distinguish among the differences among Article I clauses with respect to state sovereignty. States possessed sovereignty with regard to domestic affairs (as would be relevant to the Commerce Clause and the Patent Clause), but not foreign affairs. These powers have always resided at the national level. Therefore, it would not be appropriate to read Florida Prepaid as precluding Congress from abrogating the States' Eleventh Amendment sovereign immunity under its treaty or foreign relation powers. Cf. Zschernig v. Miller, 389 U.S. 429 (1968) (striking down, under the Supremacy Clause on the basis of foreign relations considerations, an Oregon statute that would have denied inheritance to East German heirs because the recipients could not establish that East Germany provided reciprocal inheritance rights for Americans and would not confiscate foreign heirs' rights to the proceeds of the Oregon bequest); Crosby v. National Foreign Trade Council, No. 99-474, 2000 WL 775550 (June 19, 2000) (striking down, under the Supremacy Clause on the basis of foreign relations considerations, a Massachusetts statute prohibiting state entities from doing business with U.S. or foreign companies doing business with Myanmar (which the legislation refers to as Burma)).

241. Professor Gerald Neuman has argued that the Religious Freedom Restoration Act of 1993, struck down in City of Boerne v. Flores, 521 U.S. 507 (1997), could be similarly resuscitated by re-enactment on the grounds that it implements U.S. treaty obligations under the International Covenant on Civil and Political Rights. See Gerald L. Neuman, The Global Dimension of RFRA, 14 CONST. COMMENTARY 33, 49-54 (1997).

242. See NAFTA Implementation Act, Pub. L. No. 103-182, 107 Stat. 2057 (1993) (codified at 19 U.S.C. $\$ 3311$ (1994)); Uruguay Round Agreements 
Houses) and not through formal treaty ratification (requiring assent by two-thirds of the Senate), ${ }^{243}$ the Supreme Court has recognized that the federal government may regulate foreign affairs independent of its treaty powers ${ }^{244}$ and that Congressional-Executive Agreements pass constitutional muster. ${ }^{245}$ Such Congressional-Executive Agreements have been widely used as an alternative to formal treaties during the past 60 years, ${ }^{246}$ particularly in trade-related matters. ${ }^{247}$ Even though Congress did not incorporate the terms of NAFTA and TRIPs directly into federal law, ${ }^{248}$ these agreements are binding under international law. ${ }^{249}$ Furthermore, the federal

Act, Pub. L. No. 103-465, 108 Stat. 4809 (1994) (codified at 19 U.S.C. § 3511 (1994)).

243. See U.S. CoNST., Art. II, $\S 2$.

244. See Perez v. Brownell, 356 U.S. 44, 57 (1958); United States v. CurtissWright Export Corp., 299 U.S. 304, 318 (1936).

245. See United States v. Belmont, 301 U.S. 324, 331 (1937) (stating that international agreements, like treaties, are to be given supremacy over state law); Curtiss-Wright, 299 U.S. at 318; Made in the USA Foundation v. United States, 56 F. Supp. 2d 1226 (N.D. Ala. 1999) (upholding constitutionality of NAFTA). See generally Bruce Ackerman \& David Golove, Is NAFTA Constitutional?, 108 HARV. L. REV. 801 (1995) (arguing that CongressionalExecutive Agreements are valid). But see Laurence H. Tribe, Taking Text and Structure Seriously: Reflections on Free-Form Method in Constitutional Interpretation, 108 HARV. L. REV. 1221 (1995) (questioning the constitutionality of Congressional-Executive Agreements in some circumstances); David M. Golove, Against Free-form Formalism, 73 N.Y.U. L. REV. 1791 (1998) (responding to Tribe's analysis).

246. See Ackerman \& Golove, supra note 245, at 802-03; Myres S. McDougal \& Asher Lans, Treaties and Congressional-Executive or Presidential Agreements: Interchangeable Instruments of National Policy: I, 54 YALE L.J. 181 (1945); Myres S. McDougal \& Asher Lans, Treaties and CongresionalExecutive or Presidential Agreements: Interchangeable Instruments of $\mathrm{Na}$ tional Policy: II, 54 YALE L.J. 534 (1945).

247. See LOUIS HENKIN, FOREIGN AFFAIRS AND THE U.S. CONSTITUTION 218 (1996).

248. Both implementing statutes express that no state law or its application may be declared invalid on the ground that the provision is inconsistent with the international agreement, except in an action brought for such purpose by the United States. See NAFTA Implementation Act, § 102(b)(2), 107 Stat. at 2063; Uruguay Round Agreements Act, § 102(b)(2)(A), 108 Stat. at 4817.

249. See John H. Jackson, The WTO Dispute Settlement UnderstandingMisunderstandings on the Nature of Legal Obligations, 91 AM. J. INT'L L. 60, 
government possesses authority under its foreign affairs power to override state law in order to effectuate these international agreements.

The reliance upon international treaty obligations and exclusive federal foreign relations powers as a basis for overriding state sovereign immunity for infringement of federal intellectual property rights finds support in the increasing globalization of markets for goods and services built upon intellectual property rights. It is essential for many companies to develop international if not global intellectual property right portfolios. Copyright protection is already global, ${ }^{250}$ and the Patent Cooperation Treaty ${ }^{251}$ as well as improvements in international patent institutions ${ }^{252}$ have moved the world toward a more unified system. The Internet is rapidly expanding the international exchange of intellectual property and increasing the significance of and conflict over patent, copyright, and trademark rights. ${ }^{253}$ The ease with which copyrighted and patented works can be disseminated and infringed over the Internet support the need for strong federal authority in governing intellectual property policies. ${ }^{254}$

61 (1997) (noting that a U.S. court is "bound to utilize international law obligations in its interpretation of national law"); see also The Paquete Habana, 175 U.S. 677, 700 (1900) (stating that "international law is part of our law, and must be ascertained and administered by the courts of justice of appropriate jurisdiction as often as questions of right depending upon it are duly presented for their determination").

250. The Berne Convention, which has been ratified by many of the world's nations, eliminates copyright formalities for foreign authors. See Berne Convention for the Protection of Literary and Artistic Works, July 24, 1971, S. TREATY DOC. NO. 99-27 art.5.

251. Patent Cooperation Treaty, June 19, 1970, 28 U.S.T. 7645 (1970) (ratified in the U.S. 1975).

252. See generally ARPAD BOGSCH, THE FIRST TWENTY-FIVE YEARS OF THE PATENT COOPERATION TREATY: 1970-1995 (1995); RYAN, supra note 151, at 128-32.

253. See Dan L. Burk, Patents in Cyberspace: Territoriality and Infringement on Global Computer Networks, 68 TUL. L. REV. 1 (1993); MARK A. LEMLEY ET AL., SOFTWARE AND INTERNET LAW (2000).

254. The International Intellectual Property Alliance (IIPA), a coalition representing U.S. copyright-based industries, monitors and reports on the extent of piracy of copyrighted works throughout the world. IIPA estimates international piracy losses to U.S. copyright-based industries in 1995 of $\$ 18$ to $\$ 20$ billion. See Letter from Eric H. Smith, president of IIPA, to Joseph Papovich, Acting Assistant USTR for Services Investment and Intellectual Property (vis- 
Much of the phenomenal growth of the United States economy over the past decade has been attributable to new information technologies. ${ }^{255}$ Exports having significant intellectual property content now account for over twenty-five percent of the U.S. total, a significant rise over any prior period in U.S. history. ${ }^{256}$ The information technology sector of the U.S. economy has steadily increased its share of the gross domestic product throughout the 1990s and shows no sign of slowing down. These patterns can be seen throughout the global economy. ${ }^{257}$ This vital sector of the United States economy has benefited directly from the expansion of intellectual property rights throughout the world. In order to sustain this growth, it is increasingly important that the United States both comply with international law and maintain the credibility to pressure other nations to do the same. These developments bolster the importance for the United States of fostering uniform minimum standards for the protection and enforcement of intellectual property rights throughout the world. Congressional abrogation of state sovereign immunity for infringement of federal intellectual property rights directly supports adherence to U.S. treaty obligations and the pursuit of foreign relations goals.

\section{CONCLUSION}

The Supreme Court's 1985 decision in Atascadero State Hospital v. Scanlon ${ }^{258}$ that Congress must "mak[e] its intention unmistakably clear in the language of the statute" to abrogate Eleventh Amendment immunity set in motion a chain of judicial actions and legislative reactions. Applying this standard, several appellate

ited Feb. 16, 2000) <http://www.iipa.com/html/rbi_special_301_lttr 22096.html>; see also R. MICHAEL GADBAW \& TIMOTHY J. RICHARDS, INTELLECTUAL PROPERTY RIGHTS: GLOBAL CONSENSUS, GLOBAL CONFLICT? 3 (1988) (estimating piracy of U.S. intellectual property rights of $\$ 25$ billion per year in the mid-to late-1980s).

255. See U.S. COMmerce Department, The Emerging Digital ECONOMY II (1999).

256. See GADBAW \& RICHARDS, supra note 254, at 4.

257. See The Importance of Being American: U.S. Dominance in the Computer Software Industry: A Survey of the Software Industry, ECONOMIST, May 25,1996 , at S14.

258. 473 U.S. 234 (1985). 
courts $^{259}$ ruled that Congress had not evinced such an intent in the federal copyright and patent laws and therefore dismissed infringement actions against states or state entities. Although there was relatively little evidence that states or state entities had systematically or even significantly infringed federal intellectual property rights, Congress enacted the intellectual property remedy clarification acts to protect against that risk and to promote a uniform federal intellectual property system.

However, in a parallel constitutional law development, the Supreme Court narrowed the circumstances under which Congress could abrogate state sovereign immunity. ${ }^{260}$ Therefore, when the validity of two of the intellectual property remedy clarification acts came up for review last year, the Supreme Court raised the bar against direct enforcement of state infringement of federal intellectual property in federal courts quite a bit higher. Since that time, the Fifth Circuit has struck down the third of the remedy clarification acts. These decisions, while of some symbolic significance, are not likely to change state policies respecting federal intellectual property rights. The Florida Prepaid decisions may somewhat alter the bargaining dynamic of states and intellectual property owners in a few areas such as public university research, but a broad array of legal, market, social, and political constraints will likely discourage states and state actors from becoming intellectual property pirates.

Perhaps the greatest risks of the Florida Prepaid decisions lie in their implications for the further development of a strong and enforceable international intellectual property regime. The United States has aggressively lobbied international institutions and other nations to adopt strong and comprehensive intellectual property laws. This policy has enhanced the revenues of United States intellectual property owners by enabling them to better protect and enforce their intellectual property rights abroad. By opening a conspicuous gap in the U.S. intellectual property scheme based on a distinctively

259. See Chew v. California, 893 F.2d 331 (Fed. Cir. 1990), cert. denied, 498 U.S. 810 (1990); Lane v. First Nat'l Bank, 871 F.2d 166 (1st Cir. 1989); BV Eng'g v. UCLA, 858 F.2d 1394 (9th Cir. 1988), cert. denied, 489 U.S. 1090 (1989); Richard Anderson Photography v. Brown, 852 F.2d 114 (4th Cir. 1988), cert. denied, 489 U.S. 1033 (1989).

260. See City of Boeme v. Flores, 521 U.S. 507 (1997); Seminole Tribe v. Florida, 517 U.S. 44 (1996). 
American justification, the Supreme Court's Florida Prepaid decisions jeopardize this progress. State sovereign immunity from the enforcement of federal intellectual property rights arguably violates U.S. obligations under the TRIPs, NAFTA, and WIPO Copyright Treaty agreements. Moreover, the United States has threatened and imposed trade sanctions against other nations for gaps in their domestic intellectual property regimes that, at least in their literal terms, are less open-ended than immunity in national courts for intellectual property violations by states and state entities.

Although state sovereign immunity for violations of federal intellectual property rights is likely to be of only symbolic and not substantive importance in the United States, such subtleties are easily overlooked in the international sphere. The fact that the Supreme Court ruled that Congress lacks authority under the U.S. Constitution to abrogate this immunity fuels the potential for mischaracterization and exaggeration of this gap in international diplomacy circles. In nations in which states and state enterprises play a more direct role in the economy, this type of gap in the intellectual property system could subvert the interests of intellectual property owners. Accordingly, the credibility of the United States in preventing and combating international intellectual property piracy could suffer as a result of the Florida Prepaid decisions. To the extent that the United States is hindered or delayed in achieving its goal of universal protection and effective enforcement of intellectual property rights, United States intellectual property owners will suffer a significant loss in their revenue stream, which, in turn, will reduce the incentives for engaging in creative enterprise. These international concerns provide an alternative basis for congressional abrogation of state sovereign immunity for infringement of federal intellectual property rights. 